\title{
A Novel GIS-Based Approach to Assessment Suitable Irrigation Water Using a fuzzy-Multi Indices Method in Astaneh-Kuchesfahan Plain, Iran
}

Amin Mohebbi Tafreshi

Kharazmi University

Ghazaleh Mohebbi Tafreshi ( $\nabla$ std_gh.mohebbi@khu.ac.ir)

Kharazmi University

\section{Research Article}

Keywords: Qualitative zoning, irrigation water, Fuzzy logic, Multi indices method, GIS, Astaneh-Kuchesfahan

Posted Date: August 6th, 2021

DOI: https://doi.org/10.21203/rs.3.rs-747987/v1

License: (c) (i) This work is licensed under a Creative Commons Attribution 4.0 International License. Read Full License 


\section{Abstract}

Increasing soil salinity decreased soil permeability and reduced water absorption by plant roots leading to reduced agricultural productivity. For this reason, water quality must be tested before it can be used for agricultural purposes. Accordingly, the currentresearch aimed to assess suitable irrigation water (IW) using a new GIS-basedapproach in Astaneh-Kuchesfahan plain, Iran.Fuzzy logic (FL) via GISwas used to reduce the uncertainty. Four steps were performed to receive this aim. In step 1, the values of nine indices used for agricultural water quality classification were calculated based on chemical analysis of 19 water samples in wet and dry seasons.In step 2, these indices were interpolated via ArcGIS 10.8 software. In the following, fuzzy membership functions (FMF) were used for the standardization of parameters in step 3 . Finally, in step 4 , foraggregation of the indices, several fuzzy overlay operations were used. Eventually, to identify the most accurate overlay operation,the correlations between the fuzzy memberships and operation maps were used.The results showed that the sum of absolute values for correlations (SAVC) in the dry season is higher than in the wet season.The results also showed that the "GAMMA 0.9" and"GAMMA 0.95"withthe highest SAVCare the bestoverlay operations in dry and wet seasons, respectively. According to the best operation maps, only a small southeast area has"good" groundwater quality for IWin both dry and wet seasons.

\section{Introduction}

Groundwater is the essential agricultural water resource in Iran and many other countries with a similar climate (Kheirkhah Zarkesh et al. 2012). Besides, the lower probability of groundwater pollution than other water resources has led to the great use of this resource even in areas with no surface water shortage (Mohebbi Tafreshi et al. 2019; Singh 2016). Natural purification of water during its downward movement into the ground improves groundwater quality, thus creating, in most cases, a clean and colorless water resource (Babiker et al. 2007). Water quality is vital in agriculture because low-quality water adversely affects soil and plants due to the existing physical and chemical impurities in the same, sometimes further affected by environmental factors (Mohebbi Tafreshi and Mohebbi Tafreshi 2020). Conceptually, water quality refers to the water resource's properties that affect its suitability for specific uses (Rhoades and Merrill 1976).

To a great extent, waters used for irrigation purposes, qualitatively affected by the type and amount of their dissolved salts (Nakhaei et al. 2019). Though salts are found in relatively low agricultural soils, they can increase due to the dissolution of certain rocks, including carbonate and evaporite rocks (Ravikumar and Somashekar 2010). Thus, using various indices for simultaneously detecting several dissolved ions in soils has led to classification methods for determining groundwater suitable for agricultural purposes. Accordingly, based on the selected parameter, each method can rank the groundwater quality (Ostovari et al. 2015). Some of these indices and their related classification methods are sodium percentage (Na\%), Electrical Conductivity (EC), Sodium Adsorption Ratio (SAR), Magnesium Ratio (MR), Residual Sodium Carbonate (RSC), Potential Soil Salinity (Ghanbarian et al. 2015), general soil classification or Kelly's ratios (Kelley 1951), pH, and Corrosion Rate (CR). Numerous studies attempted to examining or zoning groundwater quality for agriculture purposes by considering the relevant quality classification indices (Abera et al. 2021; Adimalla et al. 2020; Kumari and Rai 2020; Mortazavi Chamchali et al. 2021; Singh et al. 2020; Yurtseven and Randhir 2020).

In the recent decade, the applications of geographic information system (GIS) have increased in many studies all around the world (Hamzaoui-Azaza et al. 2020; Hasan and Rai 2020; Moghimi Kandlousy et al. 2016; Mohebbi Tafreshi and Mohebbi Tafreshi 2017; Muniz et al. 2020; Zhou et al. 2020). In some of these studies, a GIS-based multi indices method were used in combining with commonly used and well-known techniques such as AHP (Ghosh et al. 2020; Mega and Khechana 2021; Mohebbi Tafreshi and Mohebbi Tafreshi 2021; Saha and Paul 2021), ANP (Ahmadee 2018; Mokarram et al. 2019), TOPSIS (Gorgij et al. 2019; Liu et al. 2019; Moghimi Kandlousy et al. 2018; Seifi and Soroush 2019), and the hybrid form of WQI (Adimalla and Taloor 2020; El Mountassir et al. 2020; Fang et al. 2020; Singh et al. 2018).

Performing the qualitative classifications is always accompanied by uncertainty. Therefore, it is vital to use an applicable method that fixes this shortcoming, and FL can do it. This method is based on the fuzzy set theory presented by Zadeh (1965). It is used extensively in poorly definable engineering applications and allows flexible standardization and aggregation by partial membership. Several works worldwide used fuzzy modeling in water quality assessment based on developing water quality indices (Gholami et al. 2017; Jha et al. 2020; Kisi et al. 2019; Vadiati et al. 2019) or in the other purposes that are near to aim of our study (Akumu et al. 2015; Azimi et al. 2018; Hellwig et al. 2017; Lee et al. 2019).

Since the hybrid form of indices methods in combination with FL (Adimalla 2020; Haider et al. 2017; Jalalkamali and Jalalkamali 2018; Mohebbi Tafreshi et al. 2021a; Selvaraj et al. 2020; Zhang et al. 2021) are more efficient and accurate in comparison with the non-hybrid methods (Mohebbi Tafreshi et al. 2020b), this form of the fuzzy-multi indices was used. Using these hybrid techniques is beneficial because they can work as a widely used estimator to handle more complicated cases better than using one method (Mohebbi Tafreshi et al. 2020a).

Assessing literature shows that there has been no research (or limited researches) that used together from described quality indices for the assessment of suitable IW. Accordingly, this study aims to provide a novel GIS-based approach to assessing suitable IW using a fuzzy-multi indices method.

\section{Study area}

The study area (375000-430000N and 4100000-4150000E) is located in the $39 \mathrm{~N}$ zone of the UTM coordinate system, in the north of Gilan province, Iran (Fig. 1). The maximum average long-term annual rainfall in the study area is about $1300 \mathrm{~mm}$ (Rahnama et al. 2020). The southern parts comprise 
volcanic rocks, masses of metamorphic and sedimentary conglomerate outcrops (Fig. 2). The aquifer's constituent materials are deltaic and alluvial sediments of the Sefidrood River which the grain particles are large and create better conditions in terms of quantity and quality in the southern parts (Arezooman omidi langrudi et al. 2015; Rahnama et al. 2020). The rivers and groundwater direction in the area is the same; from the south towards the north (Caspian Sea).

Regarding land use, a vast area of the studied region is devoted to irrigated agriculture. Thick forests cover the land in the southern parts. Peanut orchards and rice farms are the main agricultural activity (Fig. 3).

\section{Data collection and preparation}

To calculating the irrigation indices, the qualitative parameters from 19 sampling wells in the wet (September) and dry (February) seasons of 2017 were performed in the study area. The parameters such as $\mathrm{pH}$, total dissolved solids (TDS), and electrical conductivity (EC) were measured with a multiprobe. The samples were analyzed at the Chemistry Laboratory of Gilan Regional Water Authority (GRWA). The quantity of the samples' main anions and cations was measured using flame photometry and titration methods. Table 1 lists the statistical analysis of the measured parameters for determining the water samples' quality in dry and wet seasons. Except for EC (micromhos/cm) and pH (which is a dimensionless parameter), all other parameters were measured in $\mathrm{meq} / \mathrm{l})$.

Table 1

statistical characteristic of the chemical components in wet and dry seasons

\begin{tabular}{|c|c|c|c|c|c|c|c|c|c|c|}
\hline \multicolumn{11}{|l|}{ WET SEASON } \\
\hline Parameter & $\mathrm{EC}$ & $\mathrm{PH}$ & $\mathrm{Ca}$ & $\mathrm{Mg}$ & $\mathrm{Na}$ & $\mathrm{K}$ & $\mathrm{HCO}_{3}$ & $\mathrm{CO}_{3}$ & $\mathrm{Cl}$ & $\mathrm{SO}_{4}$ \\
\hline Arithmetic mean & 1207.2 & 7.36 & 6.61 & 1.7 & 3.6 & 0.19 & 6.14 & 0 & 3.91 & 1.96 \\
\hline Standard Deviation & 277.74 & 0.12 & 1.61 & 0.72 & 1.51 & 0.25 & 0.98 & 0 & 1.7 & 1 \\
\hline Variant Coefficient (\%) & 23.01 & 1.63 & 24.36 & 42.35 & 41.94 & 131.58 & 15.96 & - & 43.48 & 51.02 \\
\hline Maximum & 1531 & 7.57 & 8.5 & 3.42 & 5.57 & 1.06 & 7.56 & 0 & 5.9 & 3.99 \\
\hline Minimum & 550 & 7.1 & 2.43 & 0.9 & 0.67 & 0.03 & 3.69 & 0 & 0.35 & 0.27 \\
\hline Mode & - & 7.43 & 8.1 & 1 & 4.56 & 0.09 & 5.76 & 0 & 4.1 & - \\
\hline Median & 1279 & 7.4 & 6.68 & 1.51 & 4.13 & 0.09 & 6.3 & 0 & 4.6 & 2.2 \\
\hline Range & 981 & 0.47 & 6.07 & 2.52 & 4.9 & 1.03 & 3.87 & 0 & 5.55 & 3.72 \\
\hline Skewness & -0.88 & -0.44 & -1.02 & 1.33 & -1.01 & 2.81 & -0.79 & 0 & -1.09 & -0.04 \\
\hline Variance & 77139 & 0.01 & 2.61 & 0.52 & 2.29 & 0.06 & 0.95 & 0 & 2.89 & 1 \\
\hline \multicolumn{11}{|l|}{ DRY SEASON } \\
\hline Parameter & EC & $\mathrm{PH}$ & $\mathrm{Ca}$ & $\mathrm{Mg}$ & $\mathrm{Na}$ & $\mathrm{K}$ & $\mathrm{HCO}_{3}$ & $\mathrm{CO}_{3}$ & $\mathrm{Cl}$ & $\mathrm{SO}_{4}$ \\
\hline Arithmetic mean & 906.68 & 7.62 & 3.46 & 1.78 & 3.71 & 0.06 & 3.34 & 0 & 4.28 & 1.35 \\
\hline Standard Deviation & 300.67 & 0.32 & 1.22 & 0.71 & 1.63 & 0.03 & 0.7 & 0 & 1.91 & 0.91 \\
\hline Variant Coefficient (\%) & 33.16 & 4.2 & 35.26 & 39.89 & 43.94 & 50 & 20.96 & - & 44.63 & 67.41 \\
\hline Maximum & 1430 & 8.02 & 6.84 & 2.84 & 6.26 & 0.11 & 4.5 & 0 & 7 & 2.98 \\
\hline Minimum & 326 & 6.92 & 1.57 & 0.35 & 0.63 & 0.01 & 2.07 & 0 & 0.4 & 0.15 \\
\hline Mode & 983 & 7.53 & - & - & 3.61 & 0.03 & 3.24 & 0 & - & 2.21 \\
\hline Median & 975 & 7.61 & 3.59 & 1.82 & 3.62 & 0.07 & 3.32 & 0 & 4.45 & 1.44 \\
\hline Range & 1104 & 1.1 & 5.27 & 2.49 & 5.63 & 0.1 & 2.43 & 0 & 6.6 & 2.83 \\
\hline Skewness & -0.53 & -0.62 & 0.9 & -0.59 & -0.39 & -0.14 & -0.1 & 0 & -0.64 & 0.23 \\
\hline Variance & 90405 & 0.1 & 1.49 & 0.5 & 2.65 & 0 & 0.49 & 0 & 3.66 & 0.83 \\
\hline
\end{tabular}

\section{Methodology}

To achieve the aim of this study, several steps were applied as follows:

Calculate and classification of irrigation water quality indices 
To assessing the groundwater quality for agricultural purposes, we must use the indices that examine water quality for this purpose. For example, salt content in soil is an excellent concern in waters used for agriculture. High concentrations of salt in water and soil adversely affect the quality of agricultural land. The total salt content in IWs is usually determined by measuring soil electrical conductivity (EC) in micromhos/cm (Meybeck 1987). Like other cations, sodium reacts with soil clays, and substituting the $\mathrm{Ca}$ and $\mathrm{Mg}$ ions decrease soil permeability and lower soil quality. SAR is the best measure for assessing sodium hazard in soil because it measures the degree of Ca and Mg substitution by Na ions (Todd 2006). Percent Sodium as another sodium hazard classification method is a parameter used for agricultural waters. The Wilcox (1955) and Eaton (1950) methods are used for chemically classifying waters in terms of their $\mathrm{Na} \%$ parameter. Another parameter affecting agricultural water quality is the residual sodium carbonate hazard. High levels of carbonate and bicarbonate ions increase soil RSC, whereas $\mathrm{Ca}$ and $\mathrm{Mg}$ ions reduce this index. Carbonate and bicarbonate ions react with $\mathrm{Ca}$ and $\mathrm{Mg}$ ions to form $\mathrm{MgCO}_{3}$ and $\mathrm{CaCO}_{3}$ sediments. As a result of this reaction, the concentration of Ca and $\mathrm{Mg}$ ions are lowered below that of the $\mathrm{Na}$ ion, leading to an increase in the $\mathrm{pH}$ value (Richards 1954). The measured Na's ratio to the sum of the measured $\mathrm{Ca}$ and $\mathrm{Mg}$ in a soil sample is termed the Kelly Ratio (Kelley 1951). Since increasing Na reduces soil permeability, a high KR can be identified as an indicator of reduced permeability. KR can also be used as a measure for warning against increased water alkalinity (Handa 1981). Increased Mg levels in groundwater would increase Na's destructive effects in soils with high Mg levels (or if waters containing high Mg levels are used). Increased Mg levels would gradually decrease plant water absorption capacity due to increased cation exchange. MR is used as an index for assessing magnesium hazards in groundwater (Grattan 1994). pH value is among the important parameters used for evaluating agricultural water quality (Bashir et al. 2013). The suitable $\mathrm{pH}$ range for irrigation use is from 6.5 to 8.4 (Bauder 2010). Corrosion is an electrolyte process occurring at metal surfaces, leading to the destruction and perforation of metallic walls. This problem mainly occurs due to high salinity and encrustation (Ryznar 1944). In agricultural waters, $\mathrm{CR}$ is often used for assessing the quality of waters flowing in the transfer pipes to farmland. Potential Salinity is another criterion used for evaluating groundwater quality for agricultural purposes in terms of dissolved salts. Lower levels of the water salinity increase gradually with each irrigation, thus exhibiting a cumulative effect, and higher levels of water salinity would lead to unacceptable levels of soil salinity in a shorter time. Doneen (1975) argued that even dissolved Salinity could increase soil salinity, thus creating agriculture problems. Potential Salinity as chloride concentration plus half sulfate concentration. Table 2 shows classifications of indices and parameters described in this section.

\begin{tabular}{|c|c|c|c|}
\hline Parameter & Describe & Calculation method & Classification \\
\hline \multirow{4}{*}{$\mathrm{EC}$} & \multirow{4}{*}{ Electrical Conductivity } & \multirow{4}{*}{ Field measurement } & $100-250=$ Excellent \\
\hline & & & $250-750=\mathrm{G} \infty \mathrm{d}$ \\
\hline & & & $750-2250=$ Fair \\
\hline & & & $>2250=$ Poor \\
\hline \multirow{4}{*}{ SAR } & \multirow{4}{*}{ S odium Adsorption Ratio } & \multirow{4}{*}{$\mathrm{SAR}=\frac{\mathrm{Na}^{+}}{\begin{array}{c}\mathrm{Ca}^{2+}+\mathrm{Mg}^{2+} \\
2\end{array}}$} & $<10=$ Excellent \\
\hline & & & $10-18=$ Good \\
\hline & & & $18-26=$ F air \\
\hline & & & $>26=$ Poor \\
\hline \multirow{5}{*}{$\mathrm{Na} \%$} & \multirow{5}{*}{ Soluble sodium percentage } & \multirow{5}{*}{$\mathrm{Na} \%=\frac{\mathrm{Na}^{+}+\mathrm{K}^{+}}{\mathrm{Na}^{+}+\mathrm{K}^{+}+\mathrm{Mg}^{+}+\mathrm{Ca}^{+2}} \times 100$} & $<20=$ Excellent \\
\hline & & & $20-40=$ Good \\
\hline & & & $40-60=$ Fair \\
\hline & & & $60-80=$ Poor \\
\hline & & & $>80=$ Very Poor \\
\hline \multirow{3}{*}{ RSC } & \multirow{3}{*}{ Residual Sodium Carbonate } & \multirow{3}{*}{$\mathrm{RSC}=\mathrm{CO}_{3}^{2+}+\mathrm{HCO}_{3}-\mathrm{Ca}^{2+}+\mathrm{Mg}^{2+}$} & $<1.25=$ Excellent \\
\hline & & & $1.25-2.5=$ F air \\
\hline & & & $>2.5=$ Unswited \\
\hline \multirow{2}{*}{$\mathrm{KR}$} & \multirow{2}{*}{ Kelly Ratio } & \multirow{2}{*}{$\mathrm{KR}=\frac{\mathrm{Na}^{+}}{\mathrm{Ca}^{2+}+\mathrm{Mg}^{2+}}$} & $<1=$ Suitable \\
\hline & & & $=1=$ Unsuitable \\
\hline \multirow[t]{2}{*}{ MR } & \multirow[t]{2}{*}{ Magnesium Ratio } & \multirow{2}{*}{$\mathrm{MR}=\underset{\mathrm{Ca}^{2+}+\mathrm{Mg}^{2+}}{\mathrm{Mg}^{2+}} \times 100$} & $<50=$ Suitable \\
\hline & & & $=50=$ Unsuitable \\
\hline $\mathrm{pH}$ & - & Field measurement & $6.5<\mathrm{pH}<8.5$ \\
\hline \multirow{3}{*}{$\mathrm{CR}$} & \multirow[b]{2}{*}{ Corrosively Rate } & $\mathrm{Cl}_{35.5}^{\mathrm{Cl}}+2 \mathrm{SO}_{96}^{2}$ & $<1=$ Suitable \\
\hline & & $\mathrm{CR}=\frac{\mathrm{HCO}_{3}+\mathrm{CO}_{3}^{2}}{2}$ & $=1=$ Unsuitable \\
\hline & \multirow{3}{*}{ Potential Salinity } & 1 & \\
\hline \multirow{2}{*}{ PS } & & \multirow{2}{*}{$\mathrm{PS}=\mathrm{Cl}+\frac{\mathrm{SO}_{4}^{2}}{2}$} & $<0.5=$ Excellent to good \\
\hline & & & $0.5-2=$ Good to Injurious \\
\hline
\end{tabular}

\section{Indices standardization with fuzzy membership functions}

The first step in the Fuzzy model is the standardization of the parameters with FMFs. According to fuzzy set theory, a range of values between 0 and 1 can express a set's members' value. A fuzzy set refers to a cluster whose membership of all its members, unlike double (Boolean) and triple logics, is not entirely straightforward and whose elements belong relatively to a setting that is between 0 and 1 . The fuzzy method evaluates each layer's membership in terms of its value. It considers the higher value points in the map, the appropriate location, and the lower value points as inappropriate points. Thus, a value of 0 means no full membership, and a value of 1 means full membership of the group members. Other collection members can also receive values between 0 and 1, depending on the degree of certainty of their membership in the collection and to themselves. Version 10 and above of ArcGIS software have several FMFs available in FL extension which is commonly used in many FL applications (Raines et al. 2010). Usage of any of the functions to the fuzzification concerns each criterion's identity, importance, and relationship with the goal. The application of any of these 
functions is according to the midpoint and spread indices. In this study, each function's midpoint selects according to parameter classification shown in Fig. 4. For standardization of the indices, three FMFs were employed that describes in the following section:

Fuzzy Gaussian: This function sets the input values as a normal distribution between zero and one. To execute this function, a numeric value called midpoint must normalize the input data between zero and one by taking the midpoint value normalizing the larger and smaller values to one and zero asymmetrically, respectively (Nakhaei et al. 2021; Raines et al. 2010).

Fuzzy Small: It is another fuzzy function that attempts to normalize input data. In this way, it needs a numeric value called midpoint that considers the median value or midpoint in the normal distribution diagram 0.5 and sets the values less than the midpoint to one and the values above the midpoint to zero (Raines et al. 2010).

Fuzzy Linear: This function sets the primary data linearly between zero and one (Nakhaei et al. 2021). The value of zero is allocated for the minimum data, and the value of one is assigned for the maximum data. In this function, two minimum and maximum values are required (Rahnama et al. 2020).

\section{Aggregation indices with fuzzy overlay operations}

In this step, the factors that were fuzzified are used, and the fuzzy overlap is applied. This step is located in the ArcGIS software inside the Fuzzy Overlay tool. The essential fuzzy rules used in this step include AND, OR, PRODUCT, SUM, and GAMMA. These fuzzy overlay operations (Fig. 5) will be explained as below:

Fuzzy AND: The operator's output will be the minimum so that it will select the least value among several layers that are overlaid on top of each other. That is, it extracts the minimum membership degree (Zadeh 1965).

Fuzzy OR: This operator operates precisely the opposite of the AND operator and selects the maximum membership among the fuzzy member's inputs (Zadeh 1965).

Fuzzy PRODUCT: The fuzzy membership values combined with this operator tend to be very small due to its multiplication properties. Because in this operator, several fuzzy inputs between zero and one are multiplied by each other (Zadeh 1965).

Fuzzy SUM: The output of this operator is utterly opposed to the PRODUCT operator. This operator's result is always greater than or equal to the largest value of the fuzzy membership. Therefore, this operator has an incremental mode (Zadeh 1965).

Fuzzy GAMMA: This operator is defined in terms of multiplies the "Fuzzy SUM" to the "Fuzzy PRODUCT" in the power of gamma (Y) (Lewis et al. 2014). When $y$ is selected as 1, the output will be the same as the "Fuzzy SUM", but when this parameter is selected as 0 , the composition will be the product of the same "Fuzzy PRODUCT" (Bonham-Carter 2014).

\section{Result And Discussion}

Calculation of the irrigation indices

Based on the results obtained from Table 1 and according to Table 2, the water quality classification indices for irrigation were calculated from major groundwater ions (Fig. 6) and listed in Table 3. As shown in Table 3, the quality of indices for agriculture purposes was classified as excellent in the following indices: MR (except w6 in the dry season), SAR, Na\% (just w16 and w18 in dry and w7, w15, and w19 in wet seasons), RSC, pH, KR (except w4 and w13 in the dry season), and CR (just w16 and w18 in dry and w7, w15, and w18 in wet seasons). Accordingly, w18 has the best, and w4 and w13 have the worst quality for irrigation purposes among other sample wells in dry and wet seasons, respectively. 
Table 3

The important parameters and indices which determine the IW quality of the study area in wet and dry seasons

\begin{tabular}{|c|c|c|c|c|c|c|c|c|c|}
\hline \multicolumn{10}{|c|}{ DRY SEASON } \\
\hline Sample & RSC & $\mathrm{Na} \%$ & MR & $\mathrm{KR}$ & PS & SAR & $\mathrm{CR}$ & EC & $\mathrm{pH}$ \\
\hline W1 & -1.30 & 33.29 & 31.83 & 0.48 & 3.45 & 1.59 & 1.24 & 829 & 7.08 \\
\hline W2 & -2.91 & 42.05 & 32.35 & 0.72 & 6.86 & 2.70 & 2.48 & 1234 & 6.92 \\
\hline W3 & -2.67 & 37.78 & 34.53 & 0.59 & 5.45 & 2.07 & 2.40 & 983 & 7.97 \\
\hline W4 & -0.61 & 55 & 48.07 & 1.20 & 6.03 & 3.57 & 2.25 & 983 & 7.47 \\
\hline W5 & -3.11 & 42.34 & 33.74 & 0.72 & 6.02 & 2.44 & 3.53 & 994 & 7.96 \\
\hline W6 & -0.76 & 46.39 & 62.88 & 0.85 & 4.05 & 2.48 & 1.69 & 784 & 7.45 \\
\hline W7 & -0.61 & 41.93 & 29.75 & 0.71 & 4.20 & 2.26 & 1.34 & 896 & 8.02 \\
\hline W8 & -2.92 & 38.7 & 40.71 & 0.62 & 6.28 & 2.19 & 2.82 & 1050 & 7.70 \\
\hline W9 & -2.70 & 37.74 & 42.48 & 0.59 & 5.32 & 2.06 & 2.36 & 975 & 7.48 \\
\hline W10 & -1.47 & 38.29 & 42.59 & 0.61 & 3.80 & 1.80 & 1.95 & 706 & 7.53 \\
\hline W11 & -1.51 & 42.98 & 31.73 & 0.74 & 4.62 & 2.40 & 1.90 & 911 & 7.98 \\
\hline W12 & -1.26 & 40.55 & 40.22 & 0.68 & 3.88 & 2.03 & 1.78 & 764 & 8.01 \\
\hline W13 & -2.44 & 53.4 & 27.03 & 1.13 & 7.80 & 3.76 & 3.77 & 1211 & 7.88 \\
\hline W14 & -3.73 & 43 & 15.56 & 0.75 & 8.38 & 3.00 & 2.91 & 1430 & 7.81 \\
\hline W15 & -3.69 & 47.42 & 29.31 & 0.90 & 7.69 & 3.16 & 4.70 & 1198 & 7.61 \\
\hline W16 & -0.50 & 19.94 & 13.62 & 0.25 & 0.92 & 0.56 & 0.71 & 326 & 7.69 \\
\hline W17 & -3.69 & 41.42 & 40.98 & 0.70 & 7.11 & 2.59 & 3.32 & 1173 & 7.53 \\
\hline W18 & 0.09 & 19.69 & 18.63 & 0.24 & 0.51 & 0.58 & 0.25 & 375 & 7.55 \\
\hline W19 & -0.36 & 36.68 & 23.81 & 0.57 & 1.76 & 1.27 & 1.20 & 405 & 7.17 \\
\hline \multicolumn{10}{|c|}{ WET SEASON } \\
\hline Sample & RSC & $\mathrm{Na} \%$ & MR & $\mathrm{KR}$ & PS & SAR & $\mathrm{CR}$ & EC & $\mathrm{pH}$ \\
\hline W1 & 0.51 & 42.23 & 18.55 & 0.72 & 3.13 & 2.36 & 0.78 & 936 & 7.57 \\
\hline W2 & -3.36 & 32.74 & 13.38 & 0.48 & 6.31 & 2.04 & 1.70 & 1360 & 7.28 \\
\hline W3 & -2.90 & 30.33 & 18.59 & 0.42 & 5.61 & 1.74 & 1.49 & 1239 & 7.44 \\
\hline W4 & -1.07 & 41.27 & 19.67 & 0.69 & 6.04 & 2.65 & 1.36 & 1256 & 7.25 \\
\hline W5 & -2.97 & 32.01 & 15.34 & 0.46 & 6.12 & 2.01 & 1.45 & 1382 & 7.43 \\
\hline W6 & -0.63 & 36.75 & 28.57 & 0.57 & 3.78 & 2.03 & 1.00 & 988 & 7.33 \\
\hline W7 & -1.09 & 14.66 & 13.21 & 0.11 & 1.84 & 0.45 & 0.45 & 877 & 7.45 \\
\hline W8 & -3.15 & 30.77 & 18.58 & 0.44 & 6.59 & 2.00 & 1.37 & 1517 & 7.10 \\
\hline W9 & -2.97 & 27.62 & 35.19 & 0.37 & 5.35 & 1.64 & 1.24 & 1335 & 7.15 \\
\hline W10 & -3.24 & 39.03 & 16.61 & 0.61 & 6.90 & 2.61 & 1.89 & 1480 & 7.34 \\
\hline W11 & -3.47 & 29.91 & 23.32 & 0.42 & 6.59 & 1.96 & 1.38 & 1531 & 7.26 \\
\hline W12 & -2.34 & 31.08 & 13.46 & 0.44 & 5.25 & 1.91 & 1.16 & 1355 & 7.45 \\
\hline W13 & -3.13 & 34.29 & 16.97 & 0.51 & 6.67 & 2.22 & 1.63 & 1433 & 7.43 \\
\hline W14 & -2.34 & 31.91 & 18.18 & 0.46 & 5.47 & 2.05 & 1.15 & 1469 & 7.25 \\
\hline W15 & -0.18 & 12.97 & 13.92 & 0.11 & 0.74 & 0.41 & 0.19 & 805 & 7.43 \\
\hline W16 & -1.33 & 34.17 & 14.29 & 0.44 & 3.40 & 1.57 & 1.11 & 945 & 7.28 \\
\hline W17 & -3.29 & 38.07 & 27.10 & 0.60 & 6.63 & 2.41 & 2.22 & 1279 & 7.41 \\
\hline
\end{tabular}




\begin{tabular}{|llllllllll|}
\hline \multicolumn{1}{|l|}{ DRY SEASON } \\
\hline W18 & -0.18 & 30.89 & 37.21 & 0.17 & 1.09 & 0.48 & 0.54 & 550 & 7.40 \\
W19 & -4.14 & 15.70 & 33.13 & 0.18 & 5.41 & 0.82 & 1.36 & 1200 & 7.50 \\
\hline
\end{tabular}

Interpolation of calculated irrigation indices

Figure 7 shows the prepared maps of the irrigation indices by interpolation. Accordingly, medium to high anomalies was revealed in the center to north parts in most indices. It can be related to the groundwater flow's direction (south to north) and leaching of the main ions from the sediment structures upstream of groundwater streams. Furthermore, it might have been caused due to the higher density of urban areas and agricultural lands in the center to northern parts of the plain. As can be seen, the trend of index changes in the wet and dry seasons is different for some indices. This case is well visible in the central and northern regions. As can be seen, in the dry season, the maximum rates of CR, EC, KR, Na\%, PS, and SAR are observed in the northeastern regions. However, in the wet season, precisely the opposite of the dry season, these indices' minimum rate is observed in described areas. It can be related to changes in the leaching rates and groundwater flow rates and ion exchanges between ions in the dry and wet seasons.

Indices standardization

Figures 8 and 9 show the fuzzy standardized IW indices according to fuzzy memberships. Because the RSC parameter has negative values, and the "Fuzzy Small" function cannot calculate these type values, the "Linear" function was used for this parameter. Considering that in the CR, KR, MR, EC, SAR, and PS indices, low values are more suitable in irrigation, the "Small" function was used to fuzzy standardize. Due to the suitability values between 6.5 to 8.5 as the appropriate range in the $\mathrm{pH}$ parameter, the "Gaussian" function was used. In this regard, value 7.5 was selected as the midpoint. Based on Table 2, classification values of $\mathrm{Na} \%$ ranked linearly, and the distance of each quality class to the next class is fixed. For this reason, the "Linear" function was used for this parameter. Furthermore, because the smaller values are better suited to this index, this function's decreased form was used to fuzzy standardize.

Aggregation indices

As shown in Fig. 10, in the "SUM" and the "OR" overly operations, the highest values of membership were selected that indicates they are expander operations. On the contrary, in the "PRODUCT" and the "AND" overly operations, the lowest membership's values were selected. This means they are restrictive operations. However, the "PRODUCT" is more restrictive than the "AND" function because the multiplication of the standardized indices less than one has lower values than the value of the standardized parameters (Lewis et al. 2014).

Figure 11 showed that in the "GAMMA" overlay operation, an increase in "Y" value caused the higher accuracy. In contrast to our results, some authors (Araya-Muñoz et al. 2017) believe that " $Y$ " values above 0.7 cause to decline in the accuracy. However, our results were confirmed by the research of Lewis et al. (2014), Mohebbi Tafreshi et al. (2018), Mohebbi Tafreshi et al. (2021b), Mortazavi Chamchali and Ghazifard (2019), and Mortazavi Chamchali and Ghazifard (2020). These researches were indicated that "GAMMA 0.8" and "GAMMA 0.9" are more accurate than other overlay operations.

Identify the most accurate operation

To specify the most accurate overlay operation, the correlations between the fuzzy membership and operation maps were used. For this purpose, the "Band collection statistics" tool in ArcGIS software was used.

Despite the relatively good correlation of most membership functions with overlapping operators, the lowest correlation is F-pH and F-MR in both dry and wet seasons (Table 4). However, contrary to the better trend of correlations in the dry season, for these two parameters, the correlation values are higher in the wet season. 
Table 4

The correlation between the "Fuzzy membership" and "Fuzzy overlay" raster maps. In this table, the "Fuzzy Na\%", the "Fuzzy SAR", the "Fuzzy PS", the "Fuzzy pH", the "Fuzzy RSC", the "Fuzzy EC", the "Fuzzy KR", the "Fuzzy MR" and the "Fuzzy CR" are fuzzy membership raster form of the indices and the "SUM", AND", OR, PRODUCT", the "GAMMA 0.1", the "GAMMA 0.2", the "GAMMA 0.3", the "GAMMA 0.4", the "GAMMA 0.5", the "GAMMA 0.6", the "GAMMA 0.7", the "GAMMA

0.8 ", the "GAMMA 0.9", the "GAMMA 0.95" and the "GAMMA 0.99" are fuzzy overlay raster form. The values are the correlation between the "Fuzzy membership" and "Fuzzy overlay" raster maps, and the values that have been marked with an underline, are the highest value amount in each category.

\begin{tabular}{|c|c|c|c|c|c|c|c|c|c|c|}
\hline \multicolumn{11}{|l|}{ DRY SEASON } \\
\hline Overlay vs. membership & F-CR & F-EC & $\mathrm{F}-\mathrm{KR}$ & F-MR & $\mathrm{F}-\mathrm{Na} \%$ & F-pH & F-PS & F-RSC & F-SAR & SAVC \\
\hline AND & 0.580 & 0.570 & 0.113 & 0.111 & 0.323 & 0.042 & 0.892 & -0.177 & 0.079 & 2.888 \\
\hline OR & 0.301 & 0.228 & 0.696 & -0.067 & 0.643 & 0.113 & 0.053 & -0.488 & 0.812 & 3.401 \\
\hline PRODUCT & 0.374 & 0.387 & 0.066 & 0.065 & 0.203 & 0.028 & 0.989 & -0.109 & 0.045 & 2.268 \\
\hline SUM & 0.003 & 0.003 & 0.042 & 0.016 & 0.027 & -0.001 & 0.001 & -0.014 & 0.036 & 0.143 \\
\hline GAMMA 0.1 & 0.413 & 0.435 & 0.075 & 0.073 & 0.227 & 0.030 & 0.988 & -0.120 & 0.051 & 2.411 \\
\hline GAMMA 0.2 & 0.459 & 0.491 & 0.085 & 0.083 & 0.255 & 0.032 & 0.979 & -0.134 & 0.058 & 2.576 \\
\hline GAMMA 0.3 & 0.515 & 0.556 & 0.098 & 0.097 & 0.290 & 0.034 & 0.960 & -0.152 & 0.067 & 2.770 \\
\hline GAMMA 0.4 & 0.582 & 0.631 & 0.116 & 0.114 & 0.334 & 0.037 & 0.928 & -0.176 & 0.080 & 2.998 \\
\hline GAMMA 0.5 & 0.663 & 0.716 & 0.140 & 0.139 & 0.391 & 0.041 & 0.878 & -0.209 & 0.099 & 3.276 \\
\hline GAMMA 0.6 & 0.759 & 0.806 & 0.178 & 0.175 & 0.466 & 0.048 & 0.804 & -0.261 & 0.130 & 3.628 \\
\hline GAMMA 0.7 & 0.865 & 0.891 & 0.240 & 0.226 & 0.568 & 0.059 & 0.700 & -0.348 & 0.187 & 4.083 \\
\hline GAMMA 0.8 & 0.948 & 0.931 & 0.338 & 0.277 & 0.692 & 0.074 & 0.557 & -0.492 & 0.292 & 4.601 \\
\hline GAMMA 0.9 & 0.936 & 0.860 & 0.464 & 0.277 & 0.793 & 0.083 & 0.383 & -0.681 & 0.456 & 4.934 \\
\hline GAMMA 0.95 & 0.876 & 0.777 & 0.520 & 0.241 & 0.811 & 0.081 & 0.300 & -0.766 & 0.546 & 4.919 \\
\hline GAMMA 0.99 & 0.809 & 0.695 & 0.556 & 0.196 & 0.807 & 0.077 & 0.241 & -0.817 & 0.611 & 4.807 \\
\hline \multicolumn{11}{|l|}{ WET SEASON } \\
\hline Overlay vs. membership & F-CR & F-EC & F-KR & F-MR & $\mathrm{F}-\mathrm{Na} \%$ & F-pH & F-PS & F-RSC & F-SAR & SAVC \\
\hline AND & 0.586 & 0.835 & 0.215 & -0.067 & 0.493 & 0.154 & 0.527 & -0.388 & 0.298 & 3.563 \\
\hline OR & 0.578 & 0.388 & 0.507 & -0.205 & 0.653 & 0.236 & 0.156 & -0.234 & 0.815 & 3.771 \\
\hline PRODUCT & 0.305 & 0.420 & 0.113 & 0.013 & 0.319 & 0.086 & 0.984 & -0.222 & 0.151 & 2.611 \\
\hline SUM & 0.000 & 0.000 & 0.000 & 0.000 & 0.000 & 0.000 & 0.000 & -0.000 & 0.000 & 0.000 \\
\hline GAMMA 0.1 & 0.330 & 0.447 & 0.122 & 0.013 & 0.341 & 0.092 & 0.984 & -0.238 & 0.164 & 2.733 \\
\hline GAMMA 0.2 & 0.362 & 0.479 & 0.134 & 0.014 & 0.369 & 0.101 & 0.980 & -0.259 & 0.181 & 2.878 \\
\hline GAMMA 0.3 & 0.403 & 0.515 & 0.149 & 0.015 & 0.403 & 0.111 & 0.970 & -0.285 & 0.202 & 3.054 \\
\hline GAMMA 0.4 & 0.457 & 0.556 & 0.168 & 0.018 & 0.446 & 0.126 & 0.951 & -0.318 & 0.230 & 3.270 \\
\hline GAMMA a 0.5 & 0.527 & 0.604 & 0.191 & 0.023 & 0.497 & 0.145 & 0.919 & -0.364 & 0.266 & 3.536 \\
\hline GAMMA 0.6 & 0.617 & 0.655 & 0.216 & 0.032 & 0.555 & 0.172 & 0.868 & -0.425 & 0.314 & 3.856 \\
\hline GAMMA 0.7 & 0.727 & 0.706 & 0.238 & 0.045 & 0.613 & 0.210 & 0.790 & -0.507 & 0.372 & 4.209 \\
\hline GAMMA 0.8 & 0.840 & 0.742 & 0.248 & 0.061 & 0.652 & 0.260 & 0.684 & -0.607 & 0.433 & 4.526 \\
\hline GAMMA 0.9 & 0.927 & 0.747 & 0.234 & 0.075 & 0.651 & 0.314 & 0.556 & -0.706 & 0.482 & 4.692 \\
\hline GAMMA 0.95 & 0.951 & 0.736 & 0.218 & 0.080 & 0.632 & 0.339 & 0.491 & -0.748 & 0.497 & 4.692 \\
\hline GAMMA 0.99 & 0.960 & 0.720 & 0.202 & 0.082 & 0.610 & 0.358 & 0.442 & -0.775 & 0.504 & 4.653 \\
\hline
\end{tabular}

After calculating the correlations, the SAVC of each overlay method was obtained. Accordingly, a higher SAVC amount shows the more accurate "overlay operation".

Based on the result shown in Table 4, the "GAMMA 0.9" and "GAMMA 0.95" methods with the highest SAVC are the best overlay operation in dry and wet seasons, respectively. In the following, the "GAMMA 0.95" and the "GAMMA 0.99 in the dry season, and the "GAMMA 0.9" and the "GAMMA 0.99 in 
the wet season are next ranking, respectively. Comparing the results obtained in dry and wet seasons shows that the rate of adaptation of operators in the dry season is higher than in the wet season.

\section{Conclusion}

Astaneh-Kuchesfahan plain, located in the central part of Gilan province, is one of the crucial hubs of special and unique agricultural products in Iran, including rice and peanuts. Consequently, it is very significant to assess groundwater quality for irrigating these products. Accordingly, in the current study, a new hybrid approach that uses GIS-based FL and a comprehensive model that includes most water quality assessment indices for irrigation have been developed. For this purpose, nine indices that are widely using for IW quality assessment were employed. This method was obtained in four steps. 1. The calculation of irrigation indices; 2 . Fuzzy standardization indices to scaling; 3 . Aggregation standardized indices; 4 . Identify the best overlay operation.

Based on the results obtained from the calculation of irrigation indices for each well, all sampling wells have excellent quality in RSC, SAR, and pH in both wet and dry seasons. Moreover, this has also happened for MR (except W6 that has very poor quality in the dry season) and KR (except W4 and W13 that have very poor quality in the dry season). On the other hand, PS with $84.21 \%$ in both wet and dry seasons and CR with $89.47 \%$ and $78.95 \%$ in dry and wet seasons have the worst quality, respectively. In terms of $\mathrm{Na} \%, 31.58 \%$ and $73.68 \%$ of wells have good quality in dry and wet seasons, respectively. In this regard, $10.53 \%$ and $15.79 \%$ of wells have excellent quality. Eventually, in terms of EC, $78.94 \%$ and $94.74 \%$ of wells have good quality in dry and wet seasons, respectively. Accordingly, $21.06 \%$ in the dry season and $5.26 \%$ in the wet season have good quality.

For fuzzy standardization, the "Small" (for the CR, KR, MR, EC, SAR, and PS indices), decrease form of the "Linear" (for Na\% and RSC), and the "Gaussian" fuzzy memberships (for the pH parameter) were used. In the aggregation indices step, the "OR", the "AND", the "PRODUCT", the "SUM", and the "GAMMA" (with various values) fuzzy overlay functions were used.

The correlation between the "Fuzzy membership" and "Fuzzy overlay" raster maps showed that GAMMA 0.8 for F-CR and F-EC, OR for F-KR, F-pH, and F-SAR, GAMMA 0.9 for F-MR, GAMMA 0.95 for F-Na\%, PRODUCT for F-PS, and GAMMA 0.99 for F-RSC have the highest correlation in the dry season. In this regard, GAMMA 0.99 for F-CR, F-pH, and F-RSC, OR for F-KR, F-MR, F-Na\%, and F-SAR, AND for F-EC, GAMMA 0.99 for F-pH, and PRODUCT for FPS have the highest correlation in the wet season. Despite these results, the overall accuracy based on SAVC showed that GAMMA 0.9 and GAMMA 0.95 are the most accurate overlay function in dry and wet seasons, respectively.

From the regional assessment of water quality for irrigation purposes viewpoint and according to best overlay function, in the dry season, $93.15 \%$, $5.91 \%, 0.86 \%$, and $0.08 \%$ of the study area have very poor, poor, moderate, and good quality, respectively. Accordingly, in the wet season, $85 \%, 14.2 \%$, and $0.8 \%$ of the study area have poor, medium, and good quality, respectively.

Water quality for irrigation purposes in the Astana-Kuchesfahan plain is very poor to poor, and poor to moderate in dry and wet seasons, respectively. According to the best overlay map, the dry season was found to have higher accuracy than the wet season.

The approach used in this research can provide a more comprehensive view based on more agricultural parameters and indices and make it easier to decide on water quality for irrigation purposes.

\section{Declarations}

\section{Ethical Approval}

The manuscript is not submitted to any other journal for simultaneous consideration. The work is original and not published elsewhere.

\section{Consent to Participate}

Not applicable

\section{Consent to Publish}

Not applicable

\section{Competing interests}

The authors declare no competing interests.

\section{Acknowledgments}

The authors are thankful toGilan Regional Water Authority (GRWA) and Kharazmi University for providing the necessary facilities to carry out this work.

\section{Author information}


Affiliations

Department of Applied Geology, Faculty of Earth Sciences, Kharazmi University, Tehran, Iran.

Amin Mohebbi Tafreshi \& Ghazaleh Mohebbi Tafreshi

\section{Contributions}

Conceptualization, methodology: G. Mohebbi Tafreshi and A. Mohebbi Tafreshi; software, validation, formal analysis, investigation: A. Mohebbi Tafreshi; writing: G. Mohebbi Tafreshi and A. Mohebbi Tafreshi; visualization; G. Mohebbi Tafreshi; supervision: G. Mohebbi Tafreshi.All authors read and approved the final manuscript.

\section{Corresponding author}

Correspondence to Ghazaleh Mohebbi Tafreshi (std_gh.mohebbi@khu.ac.ir).

\section{Funding}

Not applicable.

\section{Conflict of interest}

The authors declare that they have no conflict of interest.

\section{Availability of data and materials}

The datasets used and/or analyzed during the current study are available from the corresponding author on reasonable request.

\section{References}

1. Abera A, Verhoest NEC, Tilahun S, Inyang H, Nyssen J (2021) Assessment of irrigation expansion and implications for water resources by using RS and GIS techniques in the Lake Tana Basin of Ethiopia. Environ Monit Assess 193:13. https://doi.org/10.1007/s10661-020-08778-1

2. Adimalla N (2020) Groundwater quality delineation based on fuzzy comprehensive assessment method (FCAM): a case study. Arab J Geosci 13:1256. https://doi.org/10.1007/s12517-020-06265-y

3. Adimalla N, Dhakate R, Kasarla A, Taloor AK (2020) Appraisal of groundwater quality for drinking and irrigation purposes in Central Telangana, India. Groundwater Sustain Dev 10:100334. https://doi.org/10.1016/j.gsd.2020.100334

4. Adimalla N, Taloor AK (2020) Hydrogeochemical investigation of groundwater quality in the hard rock terrain of South India using Geographic Information System (GIS) and groundwater quality index (GWQI) techniques. Groundwater Sustain Dev 10:100288. https://doi.org/10.1016/j.gsd.2019.100288

5. Ahmadee M (2018) Zoning of Water Quality Using ANP and FANP Methods (Case Study: Birjand Plain). J Environ Sci Tech (JEST):in press. https://doi.org/10.22034/jest.2018.19922.2887

6. Akumu CE, Johnson JA, Etheridge D, Uhlig P, Woods M, Pitt DG, McMurray S (2015) GIS-fuzzy logic based approach in modeling soil texture: Using parts of the Clay Belt and Hornepayne region in Ontario Canada as a case study. Geoderma 239-240:13-24.

http://dx.doi.org/10.1016/j.geoderma.2014.09.021

7. Araya-Muñoz D, Metzger M, M. J., Stuart N, Wilson AMW, Carvajal D (2017) A spatial fuzzy logic approach to urban multi-hazard impact assessment in Concepción, Chile. Sci Total Environ 576:508-519. http://dx.doi.org/10.1016/j.scitotenv.2016.10.077

8. Arezooman omidi langrudi M, khashei siuki A, javadi S, hashemi SR (2015) Groundwater Vulnerability Assessment by the use of Drastic-Nw Modified model (Case study: Kuchesfehan-Astane plain). Iran J Irrigat Drain 9:75-82.

http://idj.iaid.ir/article_54855_9b57b6753b5f3b8698c04b5560888cea.pdf. Accessed 2 July 2021

9. Azimi S, Azhdary Moghaddam M, Hashemi Monfared SA (2018) Spatial assessment of the potential of groundwater quality using fuzzy AHP in GIS. Arab J Geosci 11:142. https://doi.org/10.1007/s12517-018-3484-8

10. Babiker IS, Mohamed MAA, and Hiyama T (2007) Assessing groundwater quality using GIS. Water Resour Manage 21:699-715. http://dx.doi.org/10.1007/s11269-006-9059-6

11. Bashir E, Naseem S, Pirzada T (2013) Geochemical study of groundwater of Uthal and Bela areas, Balochistan and its appraisal for drinking and irrigation water quality. Int J Agr Env 2:1-13. http://www.waterinfo.net.pk/?q=node/1027. Accessed 2 July 2021

12. Bauder TA, Waskom, R.M. and Davis, J.G. (2010) Irrigation water quality criteria. Colorado State University Extension. http://extension.colostate.edu/docs/pubs/crops/00506.pdf. Accessed 2 July 2021

13. Bonham-Carter GF (2014) Geographic Information Systems for Geoscientists: Modelling with GIS. Elsevier Science. https://books.google.com/books?id=FkKeBQAAQBAJ. Accessed 2 July 2021 
14. Doneen LD (1975) Water Quality for Irrigated Agriculture. In: Poljakoff-Mayber A, Gale J (eds) Plants in Saline Environments. Springer Berlin Heidelberg, Berlin, Heidelberg, pp 56-76. http://dx.doi.org/10.1007/978-3-642-80929-3_5

15. Eaton FM (1950) Significance of carbonate in irrigation water. Soil Sci 69:123-134. http://journals.Iww.com/soilsci/Fulltext/1950/02000/SIGNIFICANCE_OF_CARBONATES_IN_IRRIGATION_WATERS_.4.aspx. Accessed 2 July 2021

16. El Mountassir O, Bahir M, Ouazar D, Ouhamdouch S, Chehbouni A, Ouarani M (2020) The use of GIS and water quality index to assess groundwater quality of krimat aquifer (Essaouira; Morocco). SN Appl Sci 2:871. https://doi.org/10.1007/s42452-020-2653-z

17. Fang Y, Zheng T, Zheng X, Peng H, Wang H, Xin J, Zhang B (2020) Assessment of the hydrodynamics role for groundwater quality using an integration of GIS, water quality index and multivariate statistical techniques. J Environ Manag 273:111185.

https://doi.org/10.1016/j.jenvman.2020.111185

18. Ghanbarian B, Taslimitehrani V, Dong G, Pachepsky YA (2015) Sample dimensions effect on prediction of soil water retention curve and saturated hydraulic conductivity. J Hydrol 528:127-137. https://doi.org/10.1016/j.jhydrol.2015.06.024

19. Gholami V, Khaleghi MR, Sebghati M (2017) A method of groundwater quality assessment based on fuzzy network-CANFIS and geographic information system (GIS). Appl Water Sci 7:3633-3647. https://doi.org/10.1007/s13201-016-0508-y

20. Ghosh D, Mandal M, Banerjee M, Karmakar M (2020) Impact of hydro-geological environment on availability of groundwater using analytical hierarchy process (AHP) and geospatial techniques: A study from the upper Kangsabati river basin. Groundwater Sustain Dev 11:100419. https://doi.org/10.1016/j.gsd.2020.100419

21. Gorgij AD, Wu J, Moghadam AA (2019) Groundwater quality ranking using the improved entropy TOPSIS method: a case study in Azarshahr plain aquifer, east Azerbaijan, Iran. Hum Ecol Risk Assess 25:176-190. https://doi.org/10.1080/10807039.2018.1564235

22. Grattan SR (1994) Irrigation with Saline Water. In: Tanji KK, Yaron B (eds) Management of Water Use in Agriculture. Springer Berlin Heidelberg, Berlin, Heidelberg, pp 179-198. http://dx.doi.org/10.1007/978-3-642-78562-7_8

23. Haider H, Al-Salamah IS, Ghumman AR (2017) Development of Groundwater Quality Index Using Fuzzy-Based Multicriteria Analysis for Buraydah, Qassim, Saudi Arabia. Arabian J Sci Eng 42:4033-4051. https://doi.org/10.1007/s13369-017-2578-z

24. Hamzaoui-Azaza F, Ameur M, Chaouch R, Cheikha LB, Gueddari M, Carrillo-Rivera JJ (2020) Assessment of groundwater quality based on GIS and geochemical methods: coastal aquifer of Bouficha (North-Eastern Tunisia). J Coast Conservat 24:45. https://doi.org/10.1007/s11852-020-007628

25. Handa BK (1981) Technical report on hydrochemistry, water quality and water pollution in Uttar Pradesh; Central Ground Water Board, Ministry of Agriculture and Irrigation, Govt. of India, 317. http://hydrologie.org/redbooks/a150/150029.pdf. Accessed 2 July 2021

26. Hasan MSU, Rai AK (2020) Groundwater quality assessment in the Lower Ganga Basin using entropy information theory and GIS. J Cleaner Prod 274:123077. https://doi.org/10.1016/j.jclepro.2020.123077

27. Hellwig N et al. (2017) Upscaling the spatial distribution of enchytraeids and humus forms in a high mountain environment on the basis of GIS and fuzzy logic. Eur J Soil Biol 79:1-13. http://dx.doi.org/10.1016/j.ejsobi.2017.01.001

28. Jalalkamali A, Jalalkamali N (2018) Adaptive Network-based Fuzzy Inference System-Genetic Algorithm Models for Prediction Groundwater Quality Indices: a GIS-based Analysis. J Artif Intell Data Min 6:439-445. https://doi.org/10.22044/jadm.2017.1086

29. Jha MK, Shekhar A, Jenifer MA (2020) Assessing groundwater quality for drinking water supply using hybrid fuzzy-GIS-based water quality index. Water Res 179:115867. https://doi.org/10.1016/j.watres.2020.115867

30. Kelley WP (1951) Alkali soils: Their formation properties and reclamation. Reinold Publ., New York. https://books.google.com/books? id=yf4vAAAAIAAJ. Accessed 2 July 2021

31. Kheirkhah Zarkesh M, Mohebbi Tafreshi G, Majidi A, Asadian F, Mohebbi Tafreshi A (2012) Estimated volume of storable groundwater in underground dams storage with using GIS and RS (a case study of Qazvin Province). Earth Resour 4:19-26. https://www.sid.ir/en/Journal/ViewPaper.aspx?ID=269426. Accessed 2 July 2021

32. Kisi O, Azad A, Kashi H, Saeedian A, Hashemi SAA, Ghorbani S (2019) Modeling Groundwater Quality Parameters Using Hybrid Neuro-Fuzzy Methods. Water Resour Manag 33:847-861. https://doi.org/10.1007/s11269-018-2147-6

33. Kumari M, Rai SC (2020) Hydrogeochemical Evaluation of Groundwater Quality for Drinking and Irrigation Purposes Using Water Quality Index in Semi Arid Region of India. J Geol Soc India 95:159-168. https://doi.org/10.1007/s12594-020-1405-4

34. Lee K-J, Yun S-T, Yu S, Kim K-H, Lee J-H, Lee S-H (2019) The combined use of self-organizing map technique and fuzzy c-means clustering to evaluate urban groundwater quality in Seoul metropolitan city, South Korea. J Hydrol 569:685-697. https://doi.org/10.1016/j.jhydrol.2018.12.031

35. Lewis SM, Fitts G, Kelly M, Dale L (2014) A fuzzy logic-based spatial suitability model for drought-tolerant switchgrass in the United States. Comput Electron Agr 103:39-47. http://dx.doi.org/10.1016/j.compag.2014.02.006

36. Liu D et al. (2019) A resilience evaluation method for a combined regional agricultural water and soil resource system based on Weighted Mahalanobis distance and a Gray-TOPSIS model. J Cleaner Prod 229:667-679. https://doi.org/10.1016/j.jclepro.2019.04.406

37. Mega N, Khechana S (2021) Groundwater quality assessment by analytic hierarchy process (geographic information systems-based model) in Souf region (south-east of Algeria). Int J Environ Sci Tech https://doi.org/10.1007/s13762-020-03080-6 
38. Meybeck M (1987) Global chemical weathering of surficial rocks estimated from river dissolved loads. Am J Sci 287:401-428. http://dx.doi.org/10.2475/ajs.287.5.401

39. Moghimi Kandlousy A, Mohebbi Tafreshi A, Mohebbi Tafreshi G (2016) Qualitative zoning of groundwater to assessment suitable irrigation water using GIS in Kelachai Region. Territory 13:77-96. https://scholar.google.com/scholar?

$\mathrm{hl}=$ en\&as_sdt=0\%2C5\&q=Qualitative+zoning+of+groundwater+to+assessment+suitable+irrigation+water+using+GIS+in+Kelachai+Region\&btnG= . Accessed 2 July 2021

40. Moghimi Kandlousy A, Mohebbi Tafreshi A, Mohebbi Tafreshi G (2018) Locating appropriate areas of municipal waste landfill using TOPSIS method (Case study: Langroud County). J Res Environ Health 4:112-128. http://dx.doi.org/10.22038/jreh.2018.31509.1213

41. Mohebbi Tafreshi A, Mohebbi Tafreshi G (2017) Qualitative zoning of groundwater for drinking purposes in Lenjan plain using GQI method through GIS. Environ Health Eng Manag J 4:209-215. http://dx.doi.org/10.15171/ehem.2017.29

42. Mohebbi Tafreshi A, Mohebbi Tafreshi G (2021) Investigation and zoning of geo-environmental risk around the western edge of Khareshk village's oil transmission line, Iran. Earth Sci Inform:1-15. https://doi.org/10.1007/s12145-021-00645-y

43. Mohebbi Tafreshi A, Mohebbi Tafreshi G, Bijeh Keshavarzi MH (2018) Qualitative zoning of groundwater to assessment suitable drinking water using fuzzy logic spatial modelling via GIS. Water Environ J 32:607-620. http://dx.doi.org/10.1111/wej.12358

44. Mohebbi Tafreshi A, Nakhaei M, Lashkari M, Mohebbi Tafreshi G (2019) Determination of the travel time and path of pollution in Iranshahr aquifer by particle-tracking model. SN Appl Sci 1:1616. https://doi.org/10.1007/s42452-019-1596-8

45. Mohebbi Tafreshi G, Mohebbi Tafreshi A (2020) Statistical approaches and hydrochemical modeling of groundwater in the Golpayegan Plain aquifer, Iran. Model Earth Syst Environ 6:2391-2404. https://doi.org/10.1007/s40808-020-00822-w

46. Mohebbi Tafreshi G, Nakhaei M, Lak R (2020a) A GIS-based comparative study of hybrid fuzzy-gene expression programming and hybrid fuzzyartificial neural network for land subsidence susceptibility modeling. Stoch Environ Res Risk Assess 34:1059-1087. https://doi.org/10.1007/s00477-020-01810-3

47. Mohebbi Tafreshi G, Nakhaei M, Lak R (2020b) Subsidence risk assessment based on a novel hybrid form of a tree-based machine learning algorithm and an index model of vulnerability. Geocarto Int:1-23. https://doi.org/10.1080/10106049.2020.1841835

48. Mohebbi Tafreshi G, Nakhaei M, Lak R (2021a) Evaluation of Accuracy of Hybrid Model of Gene Expression Planning - Fuzzy Logic in Estimation of Land Subsidence Risk. J Geosci 31:163-172. https://doi.org/10.22071/gsj.2019.200057.1696

49. Mohebbi Tafreshi G, Nakhaei M, Lak R (2021b) Land subsidence risk assessment using GIS Fuzzy logic spatial modeling in Varamin aquifer, Iran. Geo J 86:1203-1223. https://doi.org/10.1007/s10708-019-10129-8

50. Mokarram M, Pourghasemi HR, Tiefenbacher JP (2019) Comparison analytic network and analytical hierarchical process approaches with feature selection algorithm to predict groundwater quality. Environ Earth Sci 78:625. https://doi.org/10.1007/s12665-019-8639-8

51. Mortazavi Chamchali M, Ghazifard A (2019) The use of fuzzy logic spatial modeling via GIS for landfill site selection (case study: Rudbar-Iran). Environ Earth Sci 78:305. https://doi.org/10.1007/s12665-019-8296-y

52. Mortazavi Chamchali M, Ghazifard A (2020) A comparison of fuzzy logic and TOPSIS methods for landfill site selection according to field visits, engineering geology approach and geotechnical experiments (case study: Rudbar County, Iran). Waste Manag Res. https://doi.org/10.1177/0734242X20952839

53. Mortazavi Chamchali M, Mohebbi Tafreshi A, Mohebbi Tafreshi G (2021) Utilizing GIS linked to AHP for landfill site selection in Rudbar County of Iran. Geo J 86:163-183. https://doi.org/10.1007/s10708-019-10064-8

54. Muniz DHF, Malaquias JV, Lima JEFW, Oliveira-Filho EC (2020) Proposal of an irrigation water quality index (IWQI) for regional use in the Federal District, Brazil. Environ Monit Assess 192:607. https://doi.org/10.1007/s10661-020-08573-y

55. Nakhaei M, Mohebbi Tafreshi A, Mohebbi Tafreshi G (2019) Modeling and predicting changes of TDS concentration in Varamin aquifer using GMS software. J Adv Appl Geol 9:25-37. http://dx.doi.org/10.22055/aag.2019.27539.1903

56. Nakhaei M, Mohebbi Tafreshi A, Mohebbi Tafreshi G (2021) A new approach in comparison and evaluation of the overall accuracy of six soilwater retention models using statistical benchmarks and fuzzy method. Eurasian Soil Sci 54:716-728. https://doi.org/10.1134/S1064229321050136

57. Ostovari Y, Beigi-Harchegani H, Asgari K (2015) A fuzzy logic approach for assessment and mapping of groundwater irrigation quality: a case study of Marvdasht aquifer, Iran. Arch Agron Soil Sci 61:711-723. https://doi.org/10.1080/03650340.2014.946020

58. Rahnama S, Khozeymehnezhad H, KhasheiSiuki A (2020) Comparison of Standard Drastic and Nonparametric Models Instance-Based Learning with parameter K (IBK) and the Tree Decision M5 in Determination of Groundwater Pollution Potential (Case study: Kuchesfahan- Astane plain). J Res Environ Health 5:315-329. https://doi.org/10.22038/jreh.2020.43779.1331

59. Raines GL, Sawatzky DL, Bonham-Carter GF (2010) New fuzzy logic tools in ArcGIS 10. http://www.esri.com/news/arcuser/0410/files/fuzzylogic.pdf. Accessed 2 July 2021

60. Ravikumar P, Somashekar RK (2010) Multivariate analysis to evaluate geochemistry of groundwater in varahi river basin of udupi in Karnataka (India). Ecoscan 4(2\&3):153-162. http://www.theecoscan.in/journalpdf/4202-\%20p.\%20ravikumar.pdf. Accessed 2 July 2021 
61. Rhoades JD, Merrill aSD (1976) Assessing the suitability of water for irrigation: theoretical and empirical approaches. In: Prognosis of salinity and alkalinity. FAO Soils Bull 31:69-110. http://www.fao.org/3/a-ar112e.pdf. Accessed 2 July 2021

62. Richards LA (1954) Diagnosis and Improvement of Saline and Alkali Soils. Soil Sci 78:154. http://journals.Iww.com/soilsci/Fulltext/1954/08000/Diagnosis_and_Improvement_of_Saline_and_Alkali.12.aspx. Accessed 2 July 2021

63. Ryznar JW (1944) A New Index for Determining Amount of Calcium Carbonate Scale Formed by a Water. J Am Water Works Assoc. https://books.google.com/books?id=4Q4BPwAACAAJ. Accessed 2 July 2021

64. Saha P, Paul B (2021) Identification of potential strategic sites for city planning based on water quality through GIS-AHP-integrated model. Environ Sci Pollut Res https://doi.org/10.1007/s11356-020-12292-9

65. Seifi A, Soroush F (2019) Hybridizing of TOPSIS multi criteria decision making technique with entropy for ranking of groundwater quality and groundwater pollution risk. Iran J Irrigat Drain 13:699-714. http://idj.iaid.ir/article_95436_b578a9b5b558381089d161872a4b24fa.pdf. Accessed 2 July 2021

66. Selvaraj A, Saravanan S, Jennifer JJ (2020) Mamdani fuzzy based decision support system for prediction of groundwater quality: an application of soft computing in water resources. Environ Sci Pollut Res 27:25535-25552. https://doi.org/10.1007/s11356-020-08803-3

67. Singh KK, Tewari G, Kumar S (2020) Evaluation of Groundwater Quality for Suitability of Irrigation Purposes: A Case Study in the Udham Singh Nagar, Uttarakhand. J Chem 2020:6924026. https://doi.org/10.1155/2020/6924026

68. Singh S, Ghosh NC, Gurjar S, Krishan G, Kumar S, Berwal P (2018) Index-based assessment of suitability of water quality for irrigation purpose under Indian conditions. Environ Monit Assess 190:29. https://doi.org/10.1007/s10661-017-6407-3

69. Singh VP (2016) Handbook of Applied Hydrology, Second Edition. McGraw-Hill Education. https://books.google.com/books?id=2kUBswEACAAJ. Accessed 2 July 2021

70. Todd DK (2006) Ground water hydrology, 2nd ed. John Wiley \& Sons. https://books.google.com/books?id=tiKSDeJW554C. Accessed 2 July 2021

71. Vadiati M, Nalley D, Adamowski J, Nakhaei M, Asghari-Moghaddam A (2019) A comparative study of fuzzy logic-based models for groundwater quality evaluation based on irrigation indices. J Water Land Dev 43:158-170. http://journals.pan.pl/Content/114839. Accessed 2 July 2021

72. Wilcox LV (1955) Classification and use of irrigation waters. U.S. Dept. of Agriculture, Washington DC. https://books.google.com/books? id=uKjS_1 1 trwEC. Accessed 2 July 2021

73. Yurtseven I, Randhir TO (2020) Multivariate assessment of spatial and temporal variations in irrigation water quality in Lake Uluabat watershed of Turkey. Environ Monit Assess 192:793. https://doi.org/10.1007/s10661-020-08723-2

74. Zadeh LA (1965) Fuzzy Sets. Inf Control 8:338-353. https://doi.org/10.1016/S0019-9958(65)90241-X

75. Zhang Q, Xu P, Chen J, Qian H, Qu W, Liu R (2021) Evaluation of groundwater quality using an integrated approach of set pair analysis and variable fuzzy improved model with binary semantic analysis: a case study in Jiaokou Irrigation District, east of Guanzhong Basin, China. Sci Total Environ:145247. https://doi.org/10.1016/j.scitotenv.2021.145247

76. Zhou Y, Li P, Xue L, Dong Z, Li D (2020) Solute geochemistry and groundwater quality for drinking and irrigation purposes: a case study in Xinle City, North China. Chemie der Erde 80:125609. https://doi.org/10.1016/j.chemer.2020.125609

\section{Figures}




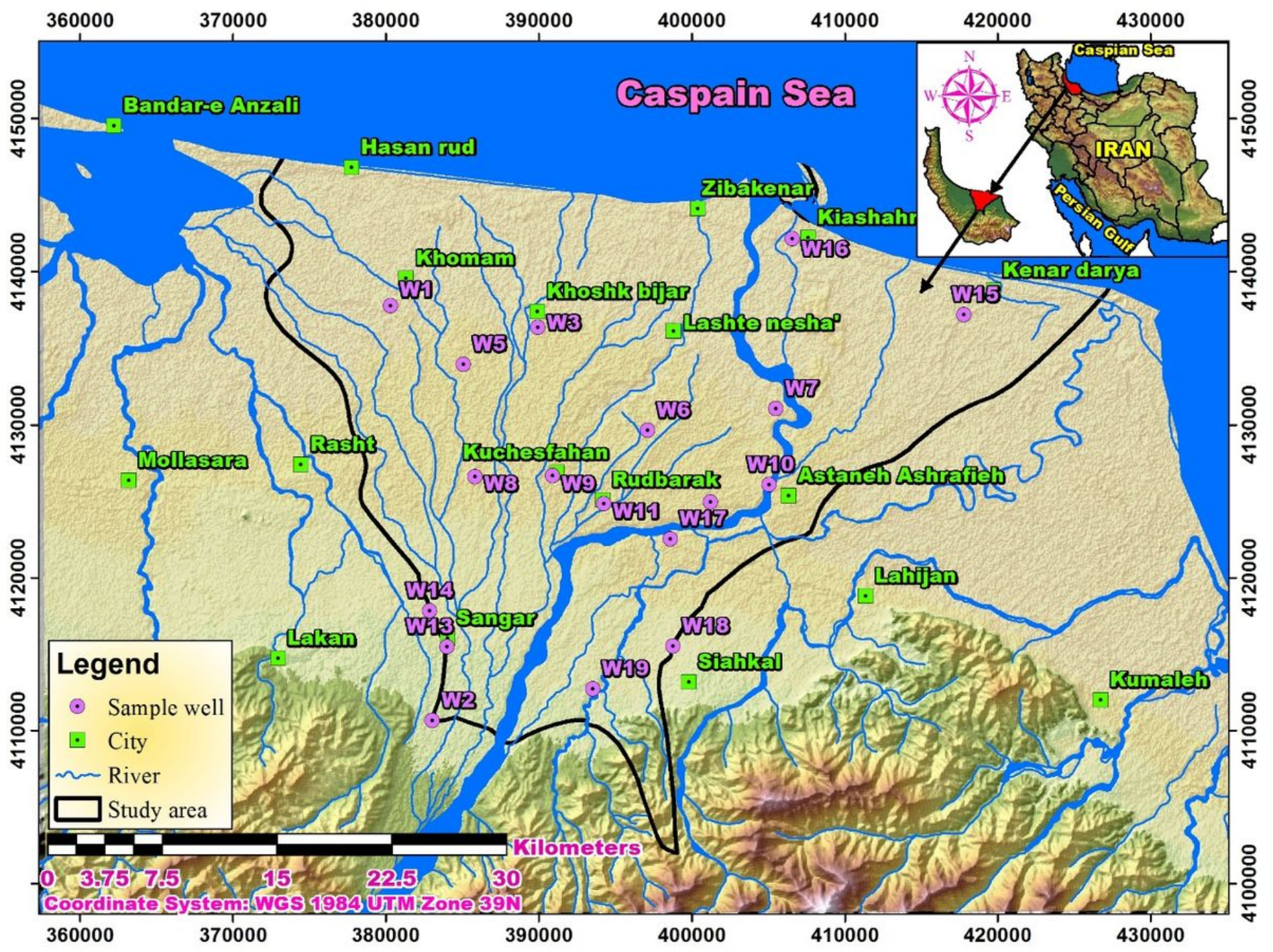

Figure 1

The location of the study area 


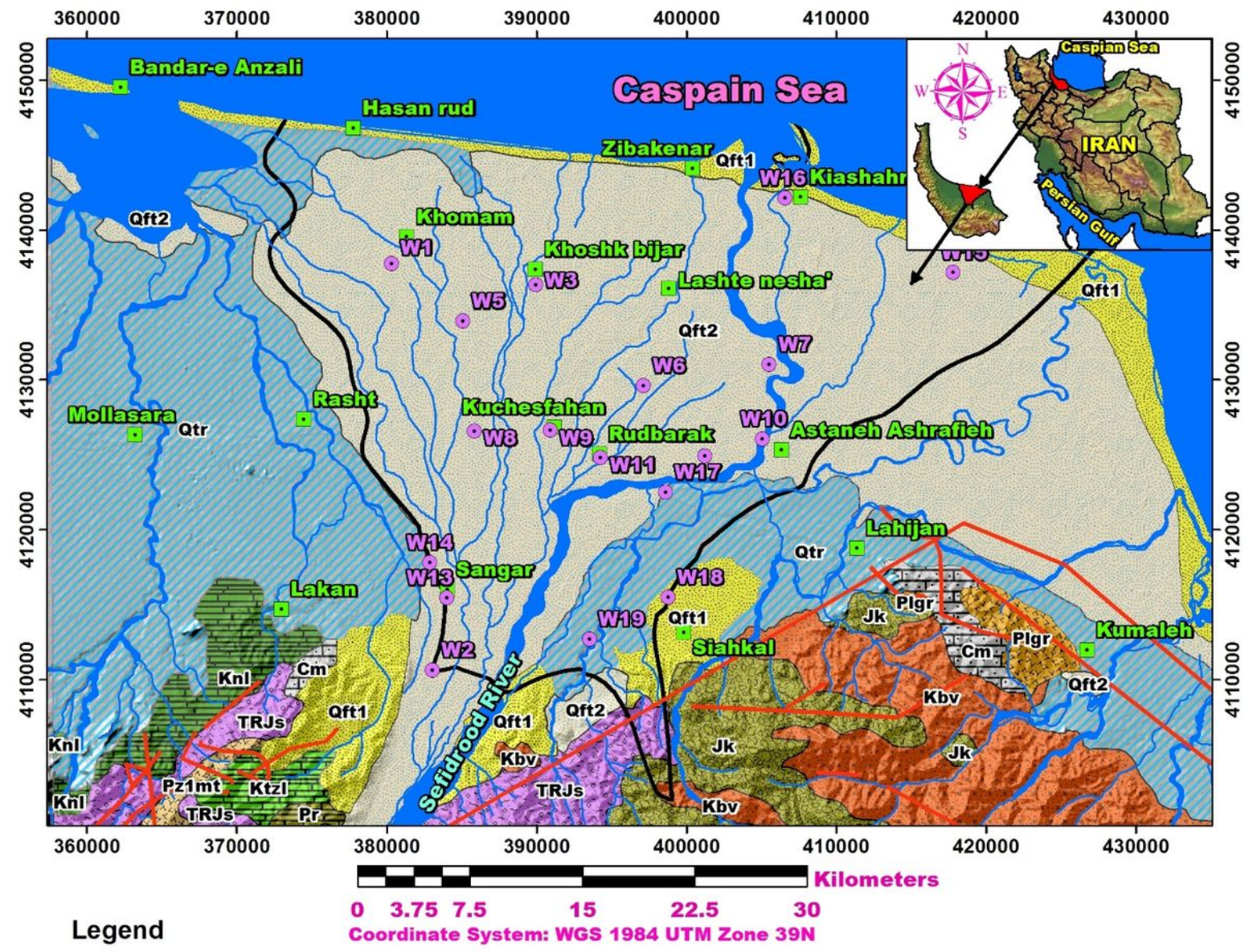

• Sample well Geo units Ktzl: Orbitolina bearing limestone

- City $\frac{1}{1} \mathrm{Cm}$ : Fossiliferous limestone

$\sim$ Fault Jk: Conglomerate

River Kbv: Basaltic volcanic

Study area

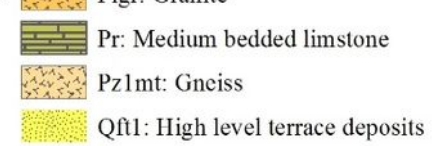

$\square$ Qft2: Low level terrace deposits

WII/, Qtr: Teravertine

2- TRJs: Shale and sandstone

Sca

Figure 2

The Geologicalmap of the study area 


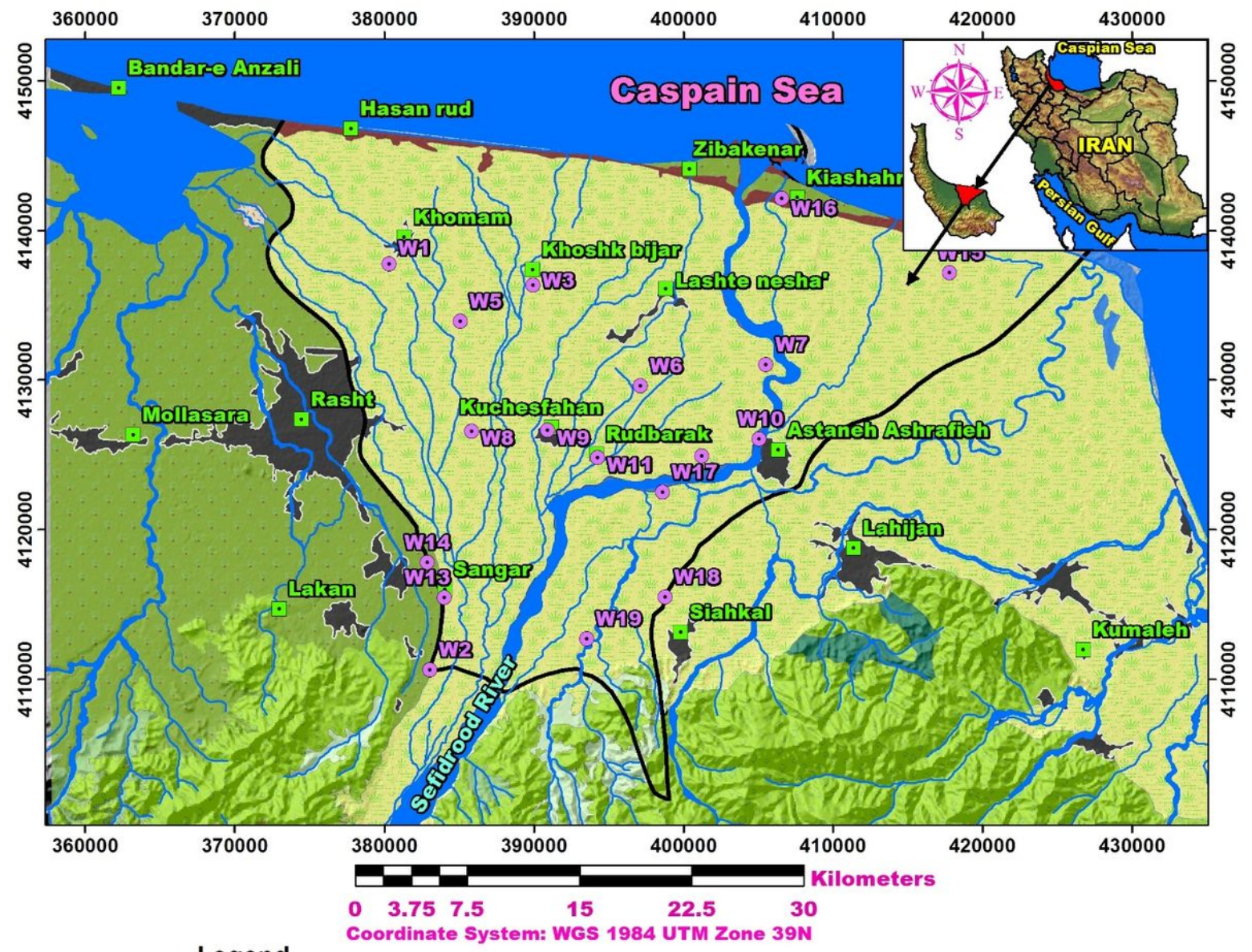

\section{Legend}

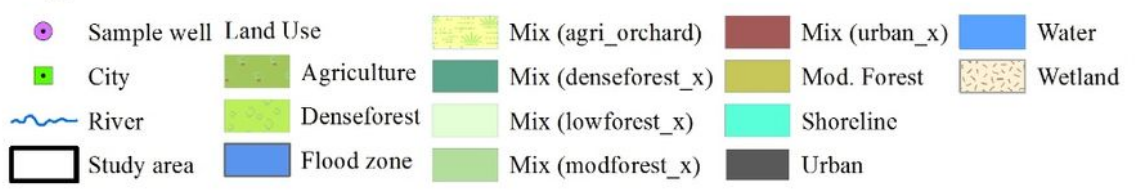

Figure 3

The land use map of the study area
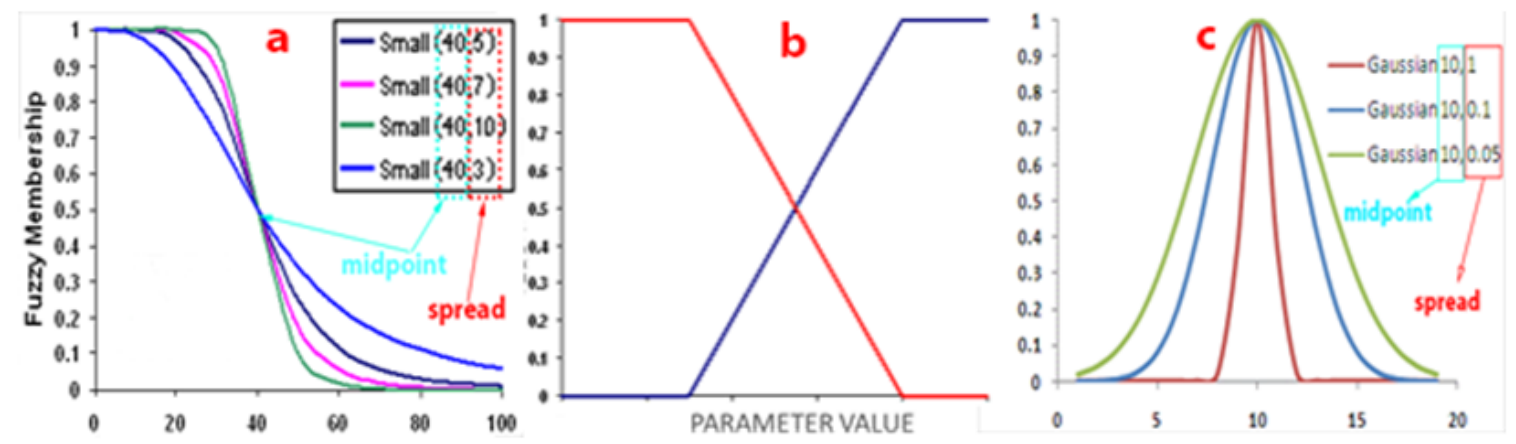

Figure 4

Fuzzy membershipsdiagrams; a: Small, b: Linear, c: Gaussian (Raines et al. 2010). 


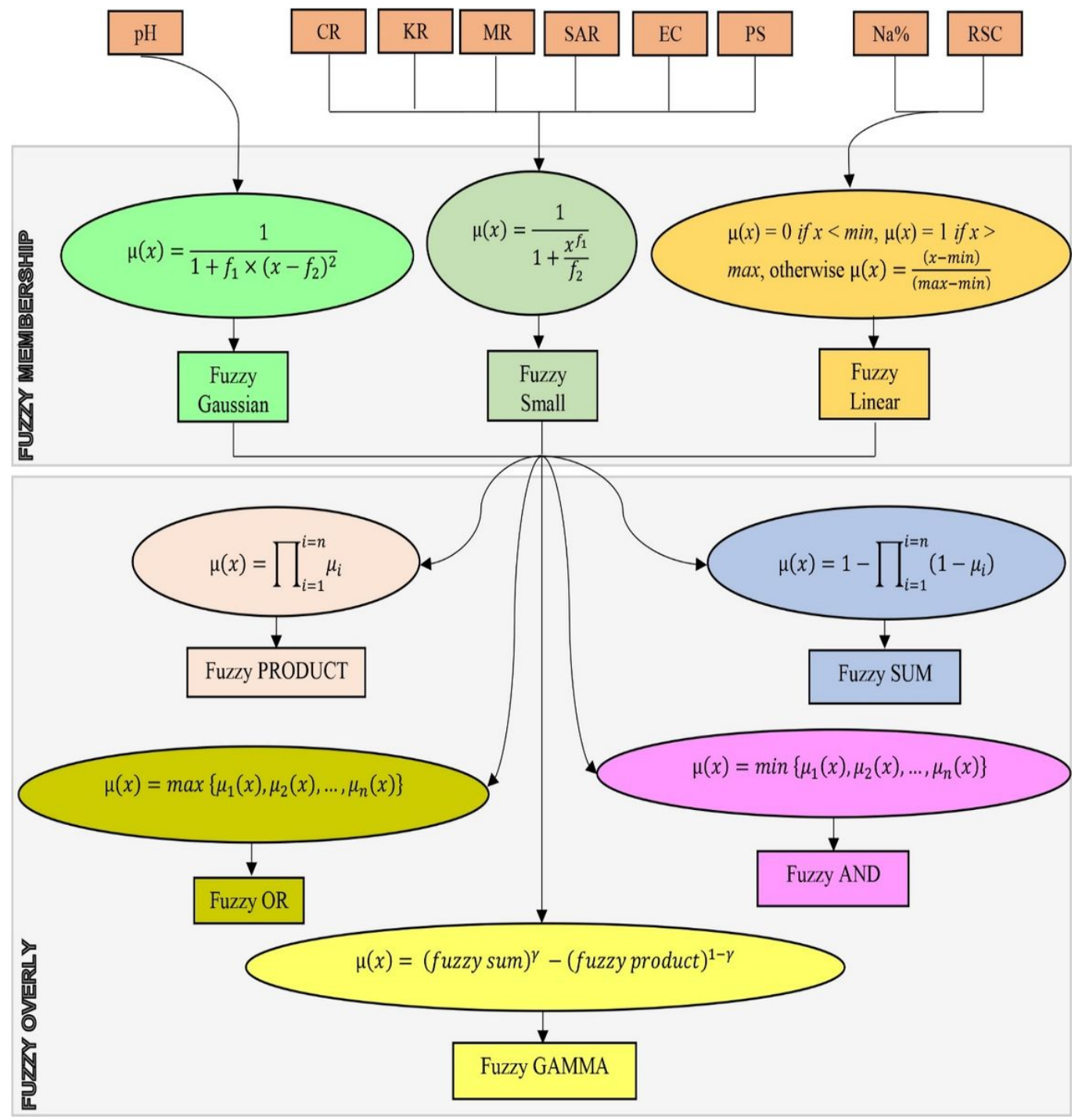

Figure 5

Fuzzy suitability model for IW quality classification. In this figure, RSC, Na\%,MR, KR, PS, SAR, CR, EC, and pH arelW quality indices, user inputs $\mathrm{f}_{-} 1$ is the spread andf_2 is the midpoint, min and max are user inputs, $\mu \_1, \mu \_2, \mu \_n$ represent membership pixels values in the relevant layer, $\mu \mathrm{i}$ is the pixels' membership value in i factor, and $\gamma$ is the power of gamma and input by the user. 


\section{DRY SEASON}

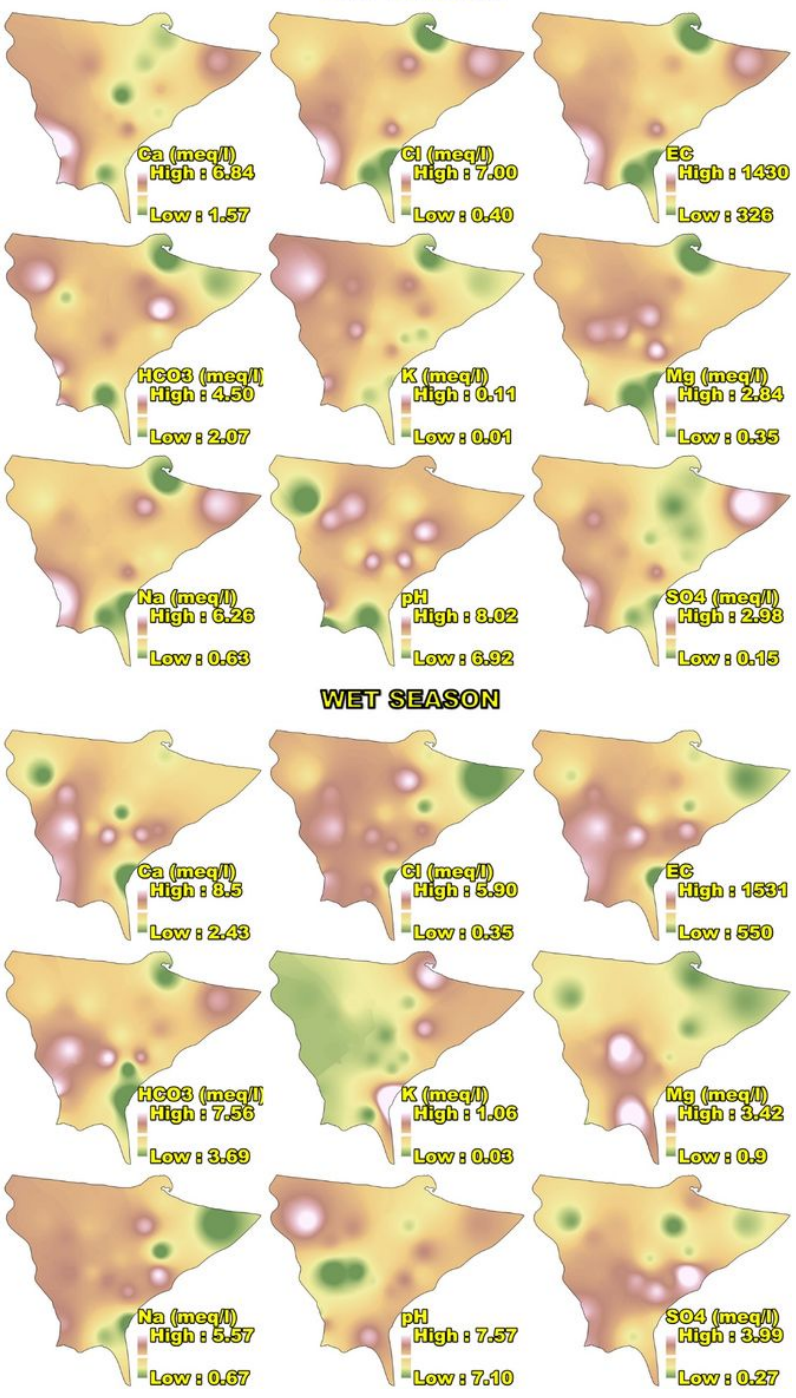

\section{Figure 6}

Interpolated maps of the concentration of significant groundwater ions in dry and wet seasons 
DRY SEASON

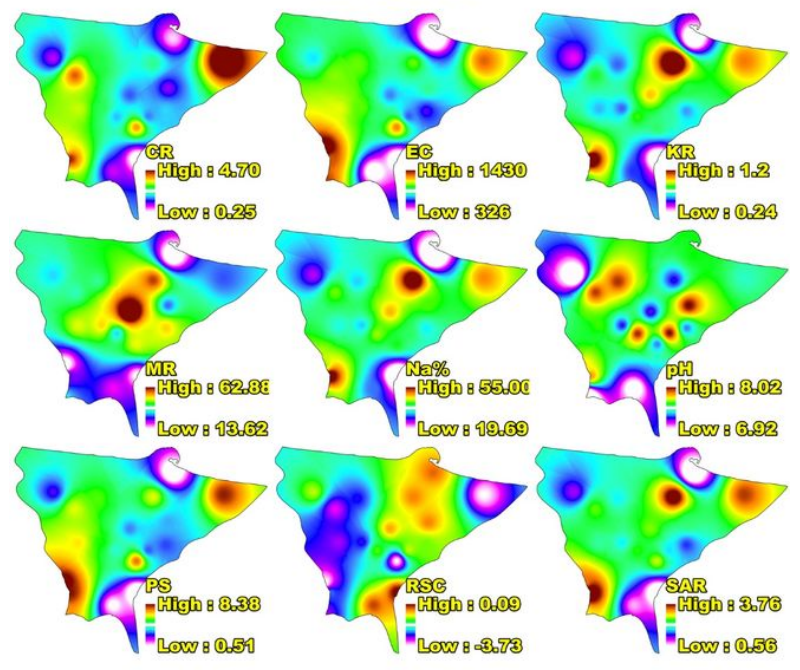

WEET SEASON

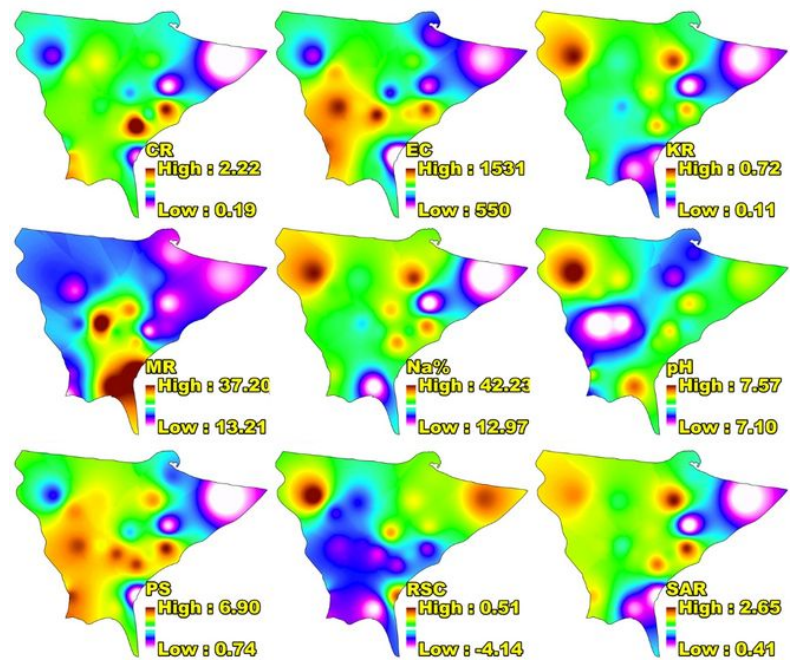

Figure 7

The interpolatedIWindices in dry and wet seasons 

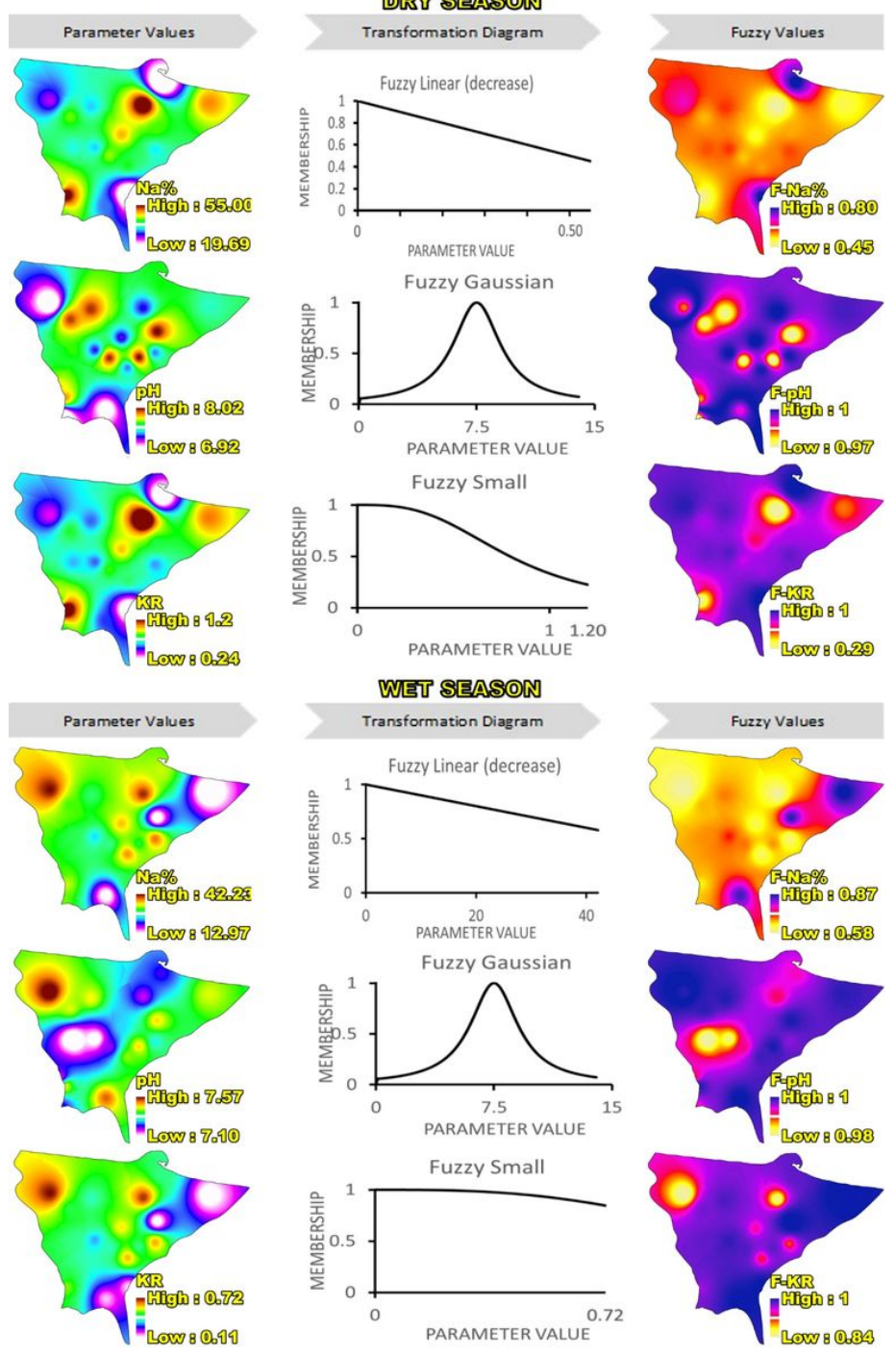

Figure 8

The procedure of fuzzy standardization using fuzzy "Linear", "Gaussian", and "Small" membership functions 

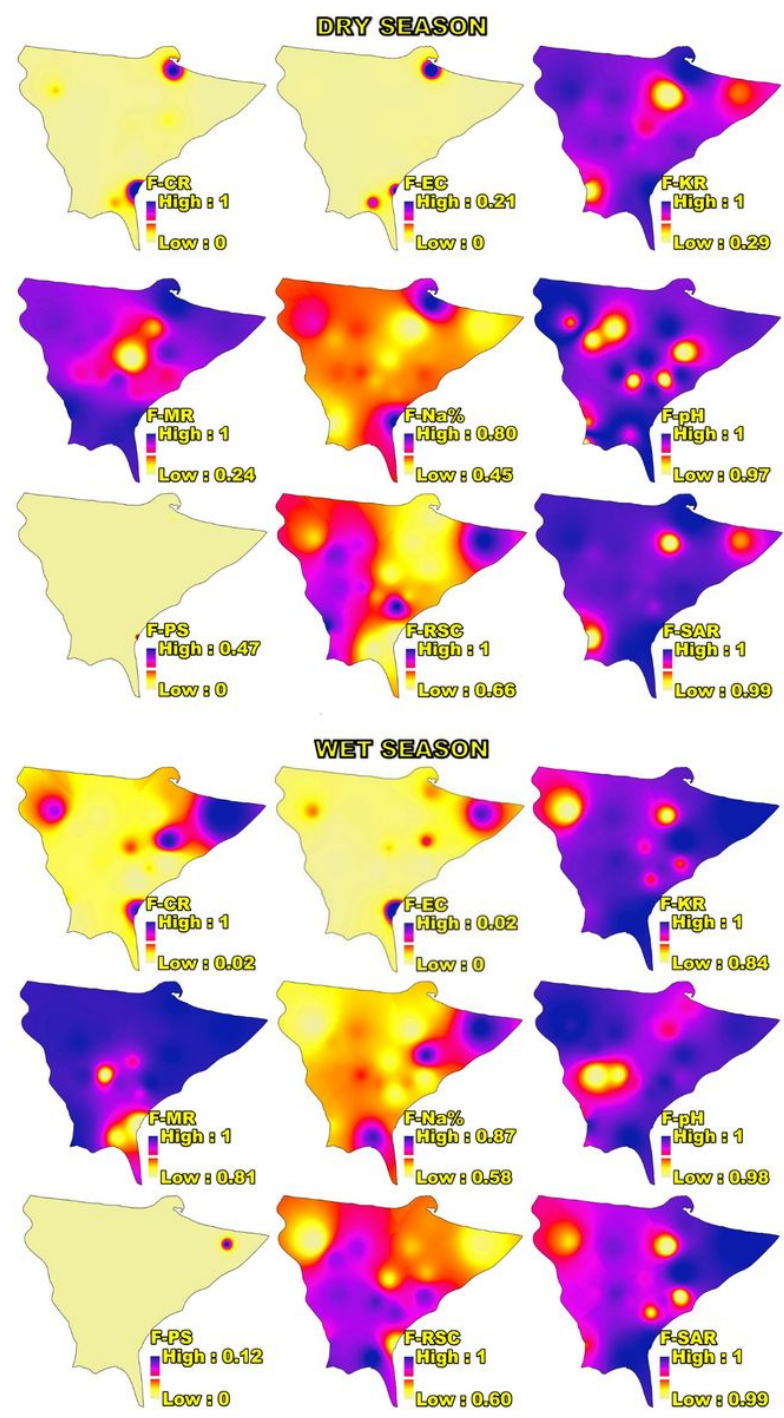

Figure 9

Fuzzy standardizedIWindices in dry and wet seasons 


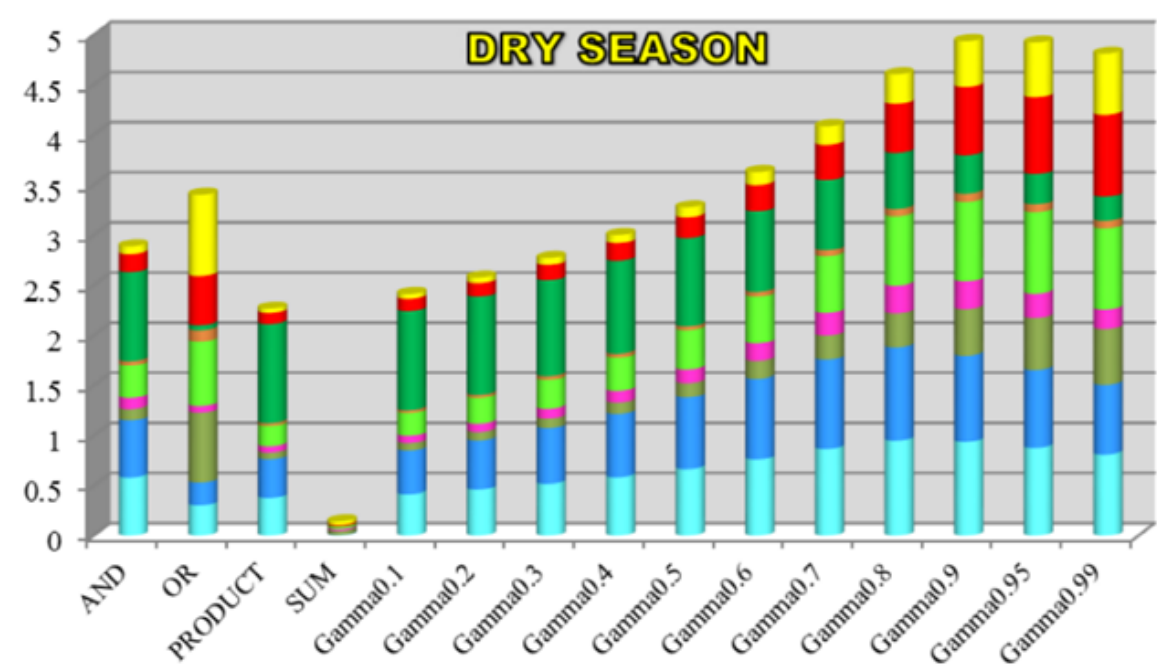

$=F-S A R$
$=F-R S C$
$=F-P S$
$\equiv F-p H$
$=F-N a \%$
$=F-M R$
$=F-K R$
$=F-E C$
$=F-C R$

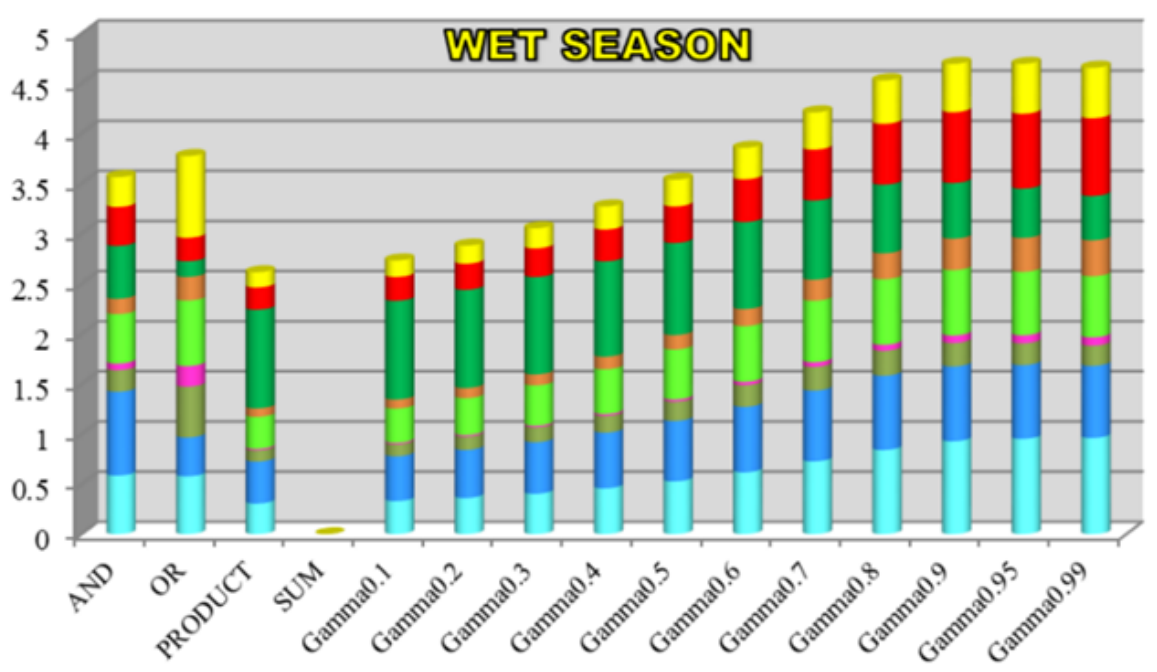

F-SAR

-F-RSC

-F-PS

in-pH

= F-Na\%

EF-MR

$=\mathrm{F}-\mathrm{KR}$

$=$ F-EC

F-CR

Figure 10

Identifying the most accurate operation according to SAVC in dry and wet seasons 


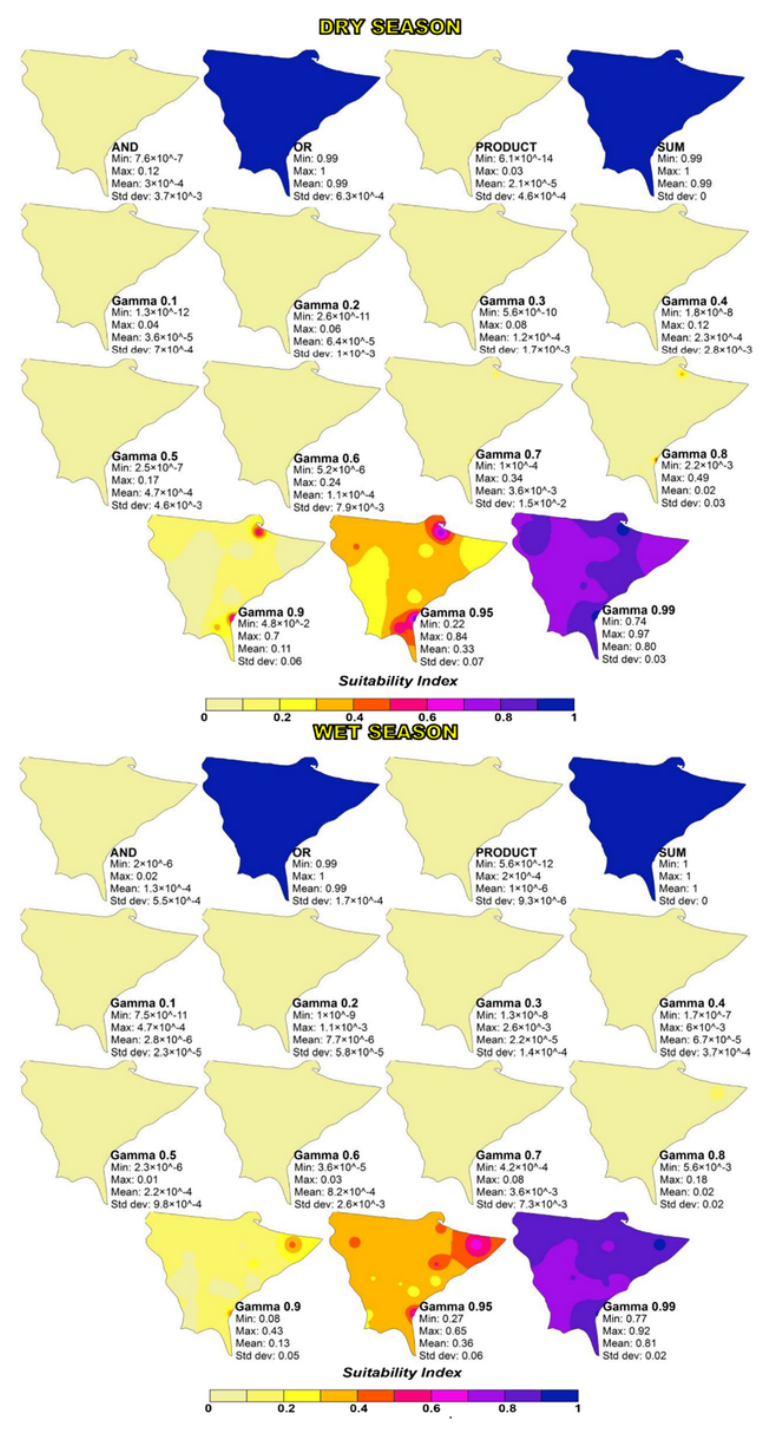

Figure 11

Thefuzzy overlay function maps indry and wet seasons
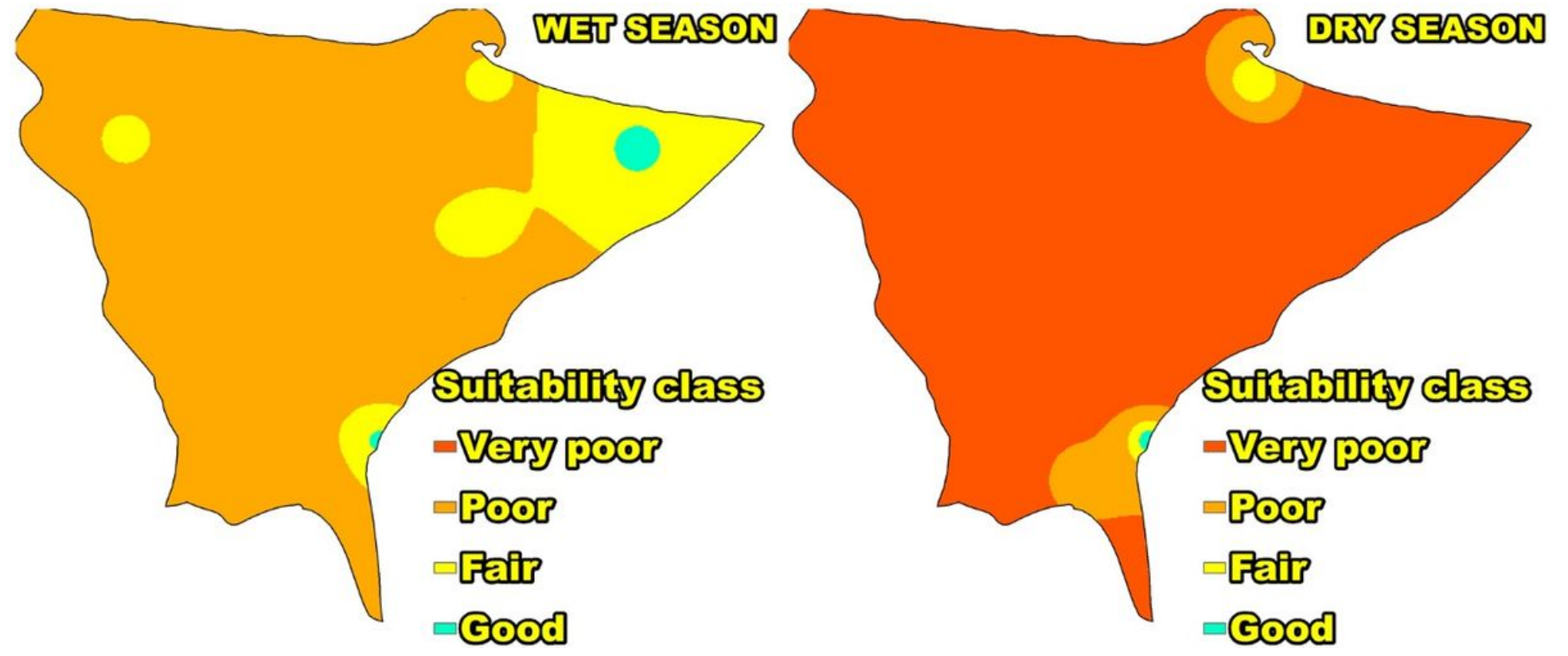

Figure 12 
The suitability class of groundwater for irrigation purposes in dry and wet seasons

Page 24/24 